\title{
Geohydrological hazards and urban development in the Mediterranean area: an example from Genoa (Liguria, Italy)
}

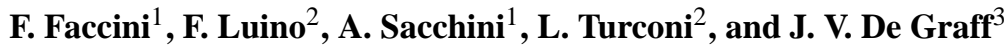 \\ ${ }^{1}$ DiSTAV, University of Genoa, Corso Europa 26, 16132 Genoa, Italy \\ ${ }^{2}$ National Research Council, Research Institute for Geohydrological Protection, Strada delle Cacce 73, 10135 Turin, Italy \\ ${ }^{3}$ California State University, M/S ST24, Fresno, CA 93740, USA \\ Correspondence to: F. Faccini (faccini@unige.it)
}

Received: 3 March 2015 - Published in Nat. Hazards Earth Syst. Sci. Discuss.: 10 April 2015

Revised: 28 October 2015 - Accepted: 19 November 2015 - Published: 9 December 2015

\begin{abstract}
The metropolitan area and the city of Genoa has become a national and international case study for geohydrological risk, mainly due to the frequency of floods. In 2014, there were landslides again, as well as flash floods that have particularly caused casualties and economic damage. The weather features of the Gulf of Genoa and the geomorphological-environmental setting of the Ligurian coastal land are the predisposing factors that determine heavy rains and their resulting effects on the ground.

This study analysed the characteristics of the main meteorological disasters that have hit Genoa since the start of the 20th century; changes in the rainfall regime are evaluated and the main stages of urbanization of the area are detailed, with the resulting changes to the drainage network, in order to identify the main causes of this high geohydrological risk. To this end, scientists have used climate data recorded at the station of Genoa University, in operation since 1833, and at Ponte Carrega station, located in the middle reach of the Bisagno stream, a well-known watercourse because of its frequent floods. Urban sprawl was evaluated through a multi-temporal mapping comparison, using maps available from the beginning of the 19th century up to the current regional technical maps.

The average air temperature in Genoa shows a statistically significant increase, while the number of rainy days displays an equally clear decrease over time. The total annual rain value does not seem to indicate rather noticeable changes. The intensity of rain in Genoa expressed as rainfall rate, i.e. the ratio of annual rainfall and number of rainy days, shows statistically significant growth.
\end{abstract}

The geohydrological vulnerability in Genoa has increased over time due to urban development which has established modifications in land use, from agricultural to urban, especially in the valley floor. Waterways have been confined and reduced to artificial channels, often covered in their final stretch; in some cases they have even been totally removed. These actions should be at least partially reversed in order to reduce the presently high hydrological risk.

\section{Introduction}

Issues surrounding determination of geohydrological risk and, more specifically, flood risk, are presently of great interest both across Europe (Hall et al., 2014; Grams et al., 2014; Blöschl et al., 2013) and in the Mediterranean area (Montanari et al., 2013; Jansà et al., 2014; Kiss et al., 2014). Within the Mediterranean area, the Italian peninsula is a focus of scientific interest in geohydrological risk because both the geology and geomorphology of the territory produce a landscape especially susceptible to geohydrological processes (Govi and Turitto, 1997). Geohydrological processes are very common in Italy with every year experiencing landslides, debris flows and flooding which affects different areas, causes severe damage to structures and infrastructure, and, too often, claims human lives (Luino, 2005). Archival documents and maps can attest to the widespread areas of the peninsula damaged by these phenomena and their persistence extending from the Roman Age to present. Table 1 reports the most important events that have occurred in Italy during the last 20 years, noting the affected region, the specific geohydrologi- 
Table 1. The most severe Italian geohydrological processes in the last 20 years.

\begin{tabular}{|c|c|c|c|c|}
\hline Date & Region/area & $\begin{array}{l}\text { Geohydrological } \\
\text { process }\end{array}$ & Damage and source & $\begin{array}{l}\text { Fatalities } \\
\qquad(>5)\end{array}$ \\
\hline 5-6 Nov 1994 & $\begin{array}{l}\text { Piedmont/Tanaro Basin and } \\
\text { Langhe Hills }\end{array}$ & $\begin{array}{l}\text { Large floods of Tanaro } \\
\text { River and some } \\
\text { tributaries, causing thousands } \\
\text { of landslides on the } \\
\text { slopes }\end{array}$ & $\begin{array}{l}\text { More than } 100 \text { urban areas flooded, } 2000 \\
\text { homeless, over USD } 10 \text { billion of overall } \\
\text { damage (Luino, 1999) }\end{array}$ & 69 \\
\hline 13 Mar 1995 & $\begin{array}{l}\text { Sicily/area of Acireale and } \\
\text { Giarre }\end{array}$ & Flash flood & $\begin{array}{l}\text { Some watercourses flooded highway, roads and } \\
\text { railways disrupted (Corriere della Sera } \\
\text { newspaper, 1995) }\end{array}$ & 6 \\
\hline 19 Jun 1996 & Tuscany/Versilia & Flash flood & $\begin{array}{l}\text { Intense rainfall: } 478 \mathrm{~mm} / 13 \mathrm{~h} \text { with a peak } \\
\text { of } 157 \mathrm{~mm} / 1 \mathrm{~h} \text {; over } 450 \text { soil slips on the } \\
\text { slopes; violent flash floods hit some villages: } \\
\text { mud and debris up to } 4-5 \mathrm{~m} \text {; } \\
1500 \text { people homeless (Caredio et al., 1998) }\end{array}$ & 14 \\
\hline 14 Oct 1996 & Calabria/Crotone & Flash flood & $\begin{array}{l}\text { Flood of Crotone; thousands of } \\
\text { people homeless; } 358 \text { farms with damages of } \\
\text { EUR } 65 \text { million (AVI PROJECT, 1996) }\end{array}$ & 6 \\
\hline 5 May 1998 & $\begin{array}{l}\text { Campania/Sarno, } \\
\text { Bracigliano, Quindici, } \\
\text { Episcopio, Siano }\end{array}$ & $\begin{array}{l}\text { Mudflows hit some } \\
\text { small towns }\end{array}$ & $\begin{array}{l}\text { Heavy rainfall (about } 140 \mathrm{~mm} / 72 \mathrm{~h} \text { ) } \\
\text { triggered over } 3 \text { billion tons of } \\
\text { flow of pyroclastic material on urbanized areas; } \\
1550 \text { people homeless, } 200 \text { houses } \\
\text { destroyed in Sarno alone; damage of } \\
\text { more than EUR } 500 \text { million (Budetta and } \\
\text { De Riso, 2004) }\end{array}$ & 159 \\
\hline 9-10 Sep 2000 & Calabria/Soverato & Flash flood & $\begin{array}{l}441 \mathrm{~mm} \text { of rain caused a rapid discharge, } \\
\text { increasing a small creek called Fiumara } \\
\text { Beltrame; a camping site was inundated, } \\
\text { provoking fatalities (Montani et al., 2003) }\end{array}$ & 14 \\
\hline $15-16$ Oct 2000 & Piedmont and Aosta Valley & $\begin{array}{l}\text { Debris flows and large } \\
\text { floods }\end{array}$ & $\begin{array}{l}\text { Some days of rainfall (more than } 700 \mathrm{~mm} \text { ): } \\
\text { floods along main watercourses and debris } \\
\text { flows on the alluvial fans; severe damage to } \\
\text { structures and infrastructure causing deaths } \\
\text { and } 40000 \text { evacuated (Tropeano et al., 2000) }\end{array}$ & 34 \\
\hline 6 and 23 Nov 2000 & $\begin{array}{l}\text { Liguria/Imperia and Savona } \\
\text { provinces }\end{array}$ & Floods & $\begin{array}{l}\text { Flooding of some streams } \\
\text { (Corriere della Sera newspaper, 2000a, b; Guzzetti } \\
\text { et al., 2004) }\end{array}$ & 7 \\
\hline 1 Oct 2009 & Sicily/Messina province & $\begin{array}{l}\text { Soil slips and mudflows } \\
\text { hit urbanized areas }\end{array}$ & $\begin{array}{l}\text { Heavy rainfall }(52 \mathrm{~mm} / 30 \mathrm{~min}, 145 \mathrm{~mm} / 6 \mathrm{~h}) \text { created } \\
\text { instability processes; many victims inside } \\
\text { houses and cars (Aronica et al., 2012) }\end{array}$ & 36 \\
\hline 3 Mar 2011 & $\begin{array}{l}\text { Marche/Sant'Elpidio a Mare } \\
\text { and Ascoli Piceno; } \\
\text { Romagna/Cervia }\end{array}$ & $\begin{array}{l}\text { Flash floods of some } \\
\text { streams }\end{array}$ & $\begin{array}{l}\text { Intense rainfall and rapid growth of some } \\
\text { streams; four people drowned in their cars } \\
\text { (Regione Marche, 2011) }\end{array}$ & 5 \\
\hline 25 Oct 2011 & Liguria/Spezia-Cinque Terre & $\begin{array}{l}\text { Soil slips and flash flood } \\
\text { affected small villages } \\
\text { on the coast }\end{array}$ & $\begin{array}{l}520 \mathrm{~mm} \text { in less than } 6 \mathrm{~h} \text {; fast discharge, } \\
\text { increasing many streams and small creeks } \\
\text { (Cevasco et al., 2013) }\end{array}$ & 12 \\
\hline 4 Nov 2011 & Liguria/Genoa & $\begin{array}{l}\text { Flash flood in urbanized } \\
\text { areas }\end{array}$ & $\begin{array}{l}500 \mathrm{~mm} \text { in } 5 \mathrm{~h} \text { provoked flash floods of all } \\
\text { watercourses which has been narrowed between buildings } \\
\text { and often covered (Silvestro et al., 2012) }\end{array}$ & 6 \\
\hline 12 Nov 2012 & Tuscany/Maremma & Floods & $\begin{array}{l}\text { Some streams flooded urbanized areas } \\
\text { (Nimbus, 2012) }\end{array}$ & 6 \\
\hline 18 Nov 2013 & Sardinia/Olbia & $\begin{array}{l}\text { Flash flood in urbanized } \\
\text { areas }\end{array}$ & $\begin{array}{l}\text { Intense rainfall }(175.2 \mathrm{~mm}) \text { caused a rapid } \\
\text { increase of the water levels in the channels; } \\
\text { large areas inundated up to the second floor } \\
\text { of houses (Repubblica newspaper, 2013; } \\
\text { Corriere della Sera newspaper, 2013) }\end{array}$ & 18 \\
\hline
\end{tabular}




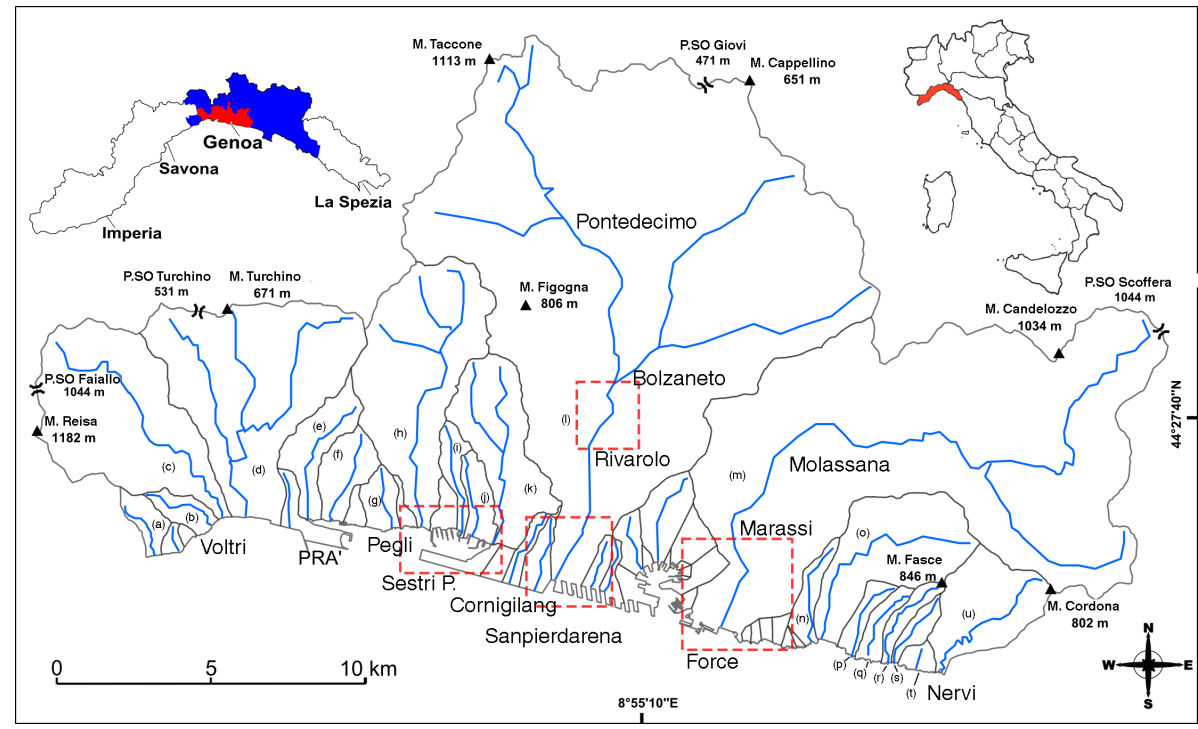

Figure 1. Main catchments and their streams, crossing Genoa in the stretch between the districts of Voltri (W) and Nervi (E): (a) Vesima; (b) Fontanelle; (c) Cerusa; (d) Leiro; (e) Branega; (f) S. Pietro; (g) S. Antonio; (h) Varenna; (i) Molinassi; (j) Cantarena; (k) Chiaravagna; (l) Polcevera; (m) Bisagno; (n) Vernazzola; (o) Sturla; (p) Priaruggia; (q) Castagna; (r) Bagnara; (s) S. Pietro; (t) Murcarolo; (u) Nervi. In the boxes (red dashed lines), from west to east: Sestri Ponente and the mouth of Chiaravagna stream, Cornigliano and the mouth of Polcevera stream, Foce and the mouth of Bisagno stream. In the centre of the figure, the red dashed box shows Polcevera stream near Bolzaneto. The red area in the inset indicates the city of Genoa; the blue area indicates the Genoan metropolitan area.

cal process that occurred and the deaths caused. Examination of these events suggests that events involving greater rainfall intensity and impacts restricted to smaller areas occur more frequently in Liguria or the nearby northern coast of Tuscany.

Within the Italian peninsula, Genoa reflects the impacts of geohydrological processes documented as early as $589 \mathrm{BC}$ and exemplified by significant events in 1404, 14071414 , 1416, 1420, 1452, 1465, 1582, 1746, 1780, 1787, and 1790. Table 2 describes significant events affecting the area around Genoa, indicating the geographic location of hydrological processes (flash flood or regular flood) during the last 2 centuries and the beginning of the current one. Of these significant events, eight took place during the 19th century, of which two events were classified as flash floods. In contrast, nine events took place during the first 70 years of the 20th century and included three events confirmed as flash floods. These nine events were not the last in the 20th century. On 7-8 October 1970 Genoa suffered probably the most catastrophic flood event of its history when an anticyclonic block contributed to the stationarity of recurring convective systems which hit Genoa and the hinterland between Voltri and Bisagno valleys. This occurred from the morning of 7 October to the early hours of 9 October, resulting in about $900 \mathrm{~mm}$ in only $24 \mathrm{~h}$ in some locations in the Polcevera Valley (catchment "l" in Fig. 1). Most streams and creeks in the municipality flooded large urbanized areas in a very short time. The most affected area was central Genoa and its western neighbourhoods. Serious damage also occurred in the other 20 municipalities within the Genoan metropolitan area. Among the most affected were the localities in the hinterland between the valley of Polcevera and Bisagno streams and Stura and Scrivia valleys in the Genoan part of the Po River Basin. As a consequence, 44 fatalities incurred, with over 2000 individuals requiring evacuation.

This sequence of destructive geohydrological events appears to have continued in the 1990s and into the 21st century. Significant damaging geohydrological events in Genoa took place in 2010, 2011 and 2014 (twice, both in October and November), claiming several victims and inflicting heavy socio-economic damage (Faccini et al., 2015a). The damaging impacts of the 2014 event are associated with a year of exceptional rainfall in Liguria with annual values of precipitation distributed in the region more than 2 times the average values (Table 3 shows the average monthly rainfall at some stations of Genoa). These geohydrological events have caused severe damage through a landslide on the railroad Genoa-Ventimiglia towards France (January), a fatality through the flooding of the Poggio stream in Bogliasco in the metropolitan area of Genoa (September), one victim through the flooding of the Bisagno in Genoa (October), two deaths provoked by a landslide near Chiavari (November) and another death through flooding in the upper Polcevera Valley - all of these occurring in the metropolitan area of Genoa (November).

In this study, the authors examine the causal factors determining a high geohydrological risk in Genoa and in its immediate surroundings, as evidenced by a large number of events and their frequency. The two factors that determine 
Table 2. Main geohydrological events involving Genoa and neighbouring areas from the 19th century to 1970. Data crossed by several sources are considered complete and reliable. The "?" symbol indicates that the historical reconstruction does not allow us to establish whether this was a regular flood or a flash flood.

\begin{tabular}{|c|c|c|c|c|}
\hline Date & Area/town & $\begin{array}{l}\text { Geo- } \\
\text { hydrological } \\
\text { process }\end{array}$ & Damage & Source \\
\hline 26 Oct 1822 & Bisagno catchment & Regular flood & $\begin{array}{l}15 \mathrm{~h} \text { of violent rainfall with more than } 760 \mathrm{~mm} \text { of } \\
\text { cumulated rainfall; flood of many streams which destroyed } \\
\text { two bridges on the Bisagno stream; mud and water up } \\
\text { to the second floor of the houses; according to sources: } \\
812 \mathrm{~mm} \text { of cumulated rainfall }\end{array}$ & $\begin{array}{l}\text { Gazzetta } \\
\text { Piemontese } \\
\text { (2 Nov 1822); } \\
\text { Gazzetta di Genova } \\
\text { (26 Oct } 1822) ; \\
\text { Pagani (1822); } \\
\text { Cati (1971) }\end{array}$ \\
\hline 1825 & $\begin{array}{l}\text { Passo Cento Croci/ } \\
\text { Vara Valley }\end{array}$ & $?$ & Floods and landslides & Almagià (1907) \\
\hline 27 Aug 1842 & Genoa & Flash flood & $\begin{array}{l}\text { Violent rainfall ( } 247 \mathrm{~mm} \text { in less than } 10 \mathrm{~h} \text { ) hit the } \\
\text { slopes behind the city, causing floodinf of some streams; mud and } \\
\text { water up to the second floor of the houses }\end{array}$ & Cati (1971) \\
\hline 13 Oct 1853 & $\begin{array}{l}\text { Sestri Levante } \\
\text { Cinqueterre }\end{array}$ & $?$ & Gromolo creek, Vara and Magra streams; three fatalities & $\begin{array}{l}\text { Gazzetta del Popolo } \\
\text { (15 Oct } 1853)\end{array}$ \\
\hline 1869 & $\begin{array}{l}\text { Lemeglio } \\
\text { (Moneglia) }\end{array}$ & $?$ & Floods and landslides in the eastern Riviera & Almagià (1907) \\
\hline 17 Oct 1872 & $\begin{array}{l}\text { Western Riviera, } \\
\text { then Bisagno and } \\
\text { Scrivia Valley }\end{array}$ & Regular flood & $\begin{array}{l}\text { Floods and landslides; overflowing of Bisagno and } \\
\text { Scrivia streams }\end{array}$ & $\begin{array}{l}\text { Almagià (1907); } \\
\text { Tropeano et al. (1993) }\end{array}$ \\
\hline 1878 & Scrivia Valley & Regular flood & Floods and landslides & Almagià (1907) \\
\hline 1885 & Deiva Marina & $?$ & Floods and landslides & Almagià (1907) \\
\hline 8 Oct 1892 & $\begin{array}{l}\text { Genoa; Bisagno } \\
\text { Valley }\end{array}$ & Flash flood & $\begin{array}{l}\text { Bisagno streams flooded at Molassana and Foce; the } \\
\text { only measure is } 181.3 \mathrm{~mm} / 24 \mathrm{~h} \text { at Genoa University, in the } \\
\text { centre of the city, west Bisagno Valley; the } \\
\text { event probably involved a very narrow area. }\end{array}$ & $\begin{array}{l}\text { Cati (1971); Russo } \\
\text { and Sacchini (1994); } \\
\text { Tropeano et al. } \\
\text { (1995) }\end{array}$ \\
\hline 1905 & Scrivia Valley & Regular flood & Floods and landslides at Vobbia and Isola del Cantone & Almagià (1907) \\
\hline 1907 & Genoa & Regular flood & $\begin{array}{l}\text { Bisagno streams flooded at Molassana and Foce. } \\
246 \mathrm{~mm} / 24 \mathrm{~h} \text { measured at Genoa University }\end{array}$ & $\begin{array}{l}\text { Cati (1971); Russo } \\
\text { and Sacchini (1994) }\end{array}$ \\
\hline 18 Jul 1908 & Genoa & Flash flood & $\begin{array}{l}\text { Bisagno streams flooded Foce district; } 238.6 \mathrm{~mm} \text { was recorded } \\
\text { at Viganego rain gauge (upper Bisagno Valley) } \\
\text { in } 9 \mathrm{~h} \text {, with the highest concentration in the } \\
\text { span 04:00-06:30 CET of } 18 \text { July; the Bisagno estimated } \\
\text { discharge was about } 420-450 \mathrm{~m}^{3} \mathrm{~s}^{-1}\end{array}$ & $\begin{array}{l}\text { Inglese et al. (1909); } \\
\text { Cati (1971); } \\
\text { Tropeano et al. } \\
\text { (1995); Cipolla et al. } \\
\text { (1999) }\end{array}$ \\
\hline 2 Nov 1926 & $\begin{array}{l}\text { Genoa; Polcevera } \\
\text { Valley }\end{array}$ & Regular flood & $\begin{array}{l}206 \mathrm{~mm} / 24 \mathrm{~h} \text { at Bolzaneto; Polcevera maximum } \\
\text { discharge about } 1050 \mathrm{~m}^{3} \mathrm{~s}^{-1}\end{array}$ & $\begin{array}{l}\text { Cati (1971); Cipolla } \\
\text { et al. (1999); } \\
\text { National } \\
\text { Hydrografic and } \\
\text { Tidal Service } \\
\text { (2/1927) }\end{array}$ \\
\hline 29-30 Oct 1945 & $\begin{array}{l}\text { Genoa; Polcevera } \\
\text { Valley, Bisagno } \\
\text { Valley }\end{array}$ & Regular flood & $\begin{array}{l}510 \mathrm{~mm} / 24 \mathrm{~h} \text { at Passo dei Giovi but the Polcevera } \\
\text { flood removed the measuring discharge instrument in } \\
\text { Bolzaneto; the Polcevera was flooded, causing damage and } \\
\text { deaths; Lagaccio dam was broken; the Bisagno } \\
\text { stream overflowed upstream of the cover; Fereggiano } \\
\text { and Molassana were also flooded; } \\
276 \mathrm{~mm} / 24 \mathrm{~h} \text { recorded at Genoa University }\end{array}$ & $\begin{array}{l}\text { Cati (1971); Cipolla } \\
\text { et al. (1993); Russo } \\
\text { and Sacchini (1994); } \\
\text { Tropeano et al. } \\
\text { (1995) }\end{array}$ \\
\hline 8-9 Nov 1951 & $\begin{array}{l}\text { Genoa; Polcevera } \\
\text { Valley; Bisagno } \\
\text { Valley }\end{array}$ & Regular flood & $\begin{array}{l}368 \mathrm{~mm} / 24 \text { at Bolzaneto, } 475 \mathrm{~mm} / 48 \mathrm{~h} ; 396 \mathrm{~mm} / \\
24 \mathrm{~h} \text { at Genoa University; Polcevera flood; Fereggiano } \\
\text { and Geirato creeks overflowed at Molassana district }\end{array}$ & $\begin{array}{l}\text { Cati (1971); Cipolla } \\
\text { et al. (1993); Russo } \\
\text { and Sacchini (1994) }\end{array}$ \\
\hline
\end{tabular}


Table 2. Continued.

\begin{tabular}{lllll}
\hline Date & Area/town & $\begin{array}{l}\text { Geo- } \\
\text { hydrological } \\
\text { process }\end{array}$ & Damage & Source \\
\hline 19 Sep 1953 & $\begin{array}{l}\text { Genoa Bisagno } \\
\text { Valley, Polcevera } \\
\text { Valley }\end{array}$ & Flash flood & $\begin{array}{l}\text { Intense rainfall: 205 mm/4 h at Genoa University } \\
(219 / 24 \mathrm{~h} \text { ) and } 330 \mathrm{~mm} \text { in the whole event at } \\
\text { Molassana district; Bisagno stream flooded, floods } \\
\text { and shallow landslides in the hinterland; damage to } \\
\text { railways (Genoa-Milan) in the Polcevera Valley and at } \\
\text { the aqueduct; damage estimated at ITL 50 billion } \\
\text { (more than EUR 25 million) }\end{array}$ & $\begin{array}{l}\text { Cati (1971); Cipolla } \\
\text { et al. (1993); Russo } \\
\text { and Sacchini (1994) }\end{array}$ \\
\hline 14 Aug 1963 & Genoa Voltri & Flash flood & Floods and damage at Voltri district & Cati (1971) \\
\hline 1 Nov 1968 & Savona, Albisola & Regular flood & $\begin{array}{l}\text { Violent rainfall and consequent floods: Albisola, Varazze } \\
\text { and Savona towns were inundated; some bridges were } \\
\text { and Varazze towns }\end{array}$ & Cipolla et al. (1999) \\
& & & &
\end{tabular}

Table 3. Monthly average rainfall and yearly total in the Genoan area. Sources: Italian Air Force (2009); ARPAL (2013).

\begin{tabular}{lccccccccccccc}
\hline Rain gauge station & Jan & Feb & Mar & Apr & May & Jun & Jul & Aug & Sept & Oct & Nov & Dec & Total \\
\hline Genoa University & 111 & 99 & 108 & 99 & 84 & 64 & 37 & 65 & 122 & 197 & 176 & 124 & 1286 \\
Sestri Ponente, Genoa & 102 & 74 & 82 & 88 & 72 & 58 & 24 & 69 & 136 & 171 & 109 & 93 & 1078 \\
Ponte Carrega, Genoa & 125 & 81 & 86 & 99 & 81 & 59 & 38 & 89 & 141 & 208 & 185 & 127 & 1319 \\
\hline
\end{tabular}

the geological risk are subsequently analysed: the incidence of short and intense rainfall events and the vulnerability determined by the urban sprawl (Faccini et al., 2014). The rainfall incidence was assessed primarily by using the climatic data of the time series recorded by the centuries-old station at Genoa University. By studying historic urban development it is noteworthy that population and infrastructure are more and more concentrated around areas exposed to risk. This development has taken place and is continuing, with a locally unique combination of meteorological, climatic and geographical factors that lead to geohydrological hazard events that have made Genoa emblematic of the recent increase in flooding risk around the Mediterranean area.

Analysing the flood events from the mid-20th century (post-war) to present, the aim of the paper is to assess whether the growth of the geohydrological risk is attributable to increasing climate hazards, i.e. more frequent, intense storm events, or to greater urban vulnerability, i.e. expanded area or topographic alteration, or to a combination of both hazards and vulnerability. The study results could be very helpful in terms of flood analysis and risk reduction and serve as a framework for similar studies in other urbanized areas.

\section{General description of Genoa}

\subsection{Geographical features of Genoa}

Early archeological finds, dating from the 6th and 5th centuries $\mathrm{BC}$, testify to the primitive population trading with the Greek at the future site of Genoa. However, the harbour was probably used much earlier, perhaps by the Etruscans. During the Middle Ages, Genoa was a very important maritime republic trading all over the world between the Atlantic Ocean and China. Today, Genoa is home to one of the most important harbours in both Europe and Italy due to its strategic position for trade between northern Europe and the Mediterranean Sea. It serves as a transit point between the Ligurian Sea and important areas of the Po Valley. Consequently, Genoa is one of the 10 Italian metropolitan cities, with an urban area of over $500 \mathrm{~km}^{2}$ in which 600000 inhabitants live (from Voltri to Nervi) within a more extensive metropolitan area, covering a total amount of $4000 \mathrm{~km}^{2}$ and hosting a population of 1.5 million of inhabitants, distributed in the central part of the Ligurian coastal arch (CityRailways, 2011).

The area of Genoa is characterized by a complex morphology determined by the Alpine-Apennine system which hosts relief extending from peaks between 1000 and $2000 \mathrm{~m}$, rapidly descending towards the Ligurian Sea. The resulting hydrographic network consists of numerous steep and short watercourses that can attain a concentration time of less than an hour during floods.

Three catchments have an area of more than $4 \mathrm{~km}^{2}$ but less than $10 \mathrm{~km}^{2}$ (Fig. 1), and moving from west to east they are Branega (e), S. Pietro (f) and Nervi (u). Five basins, Cerusa (c), Leiro (d), Varenna (h), Chiaravagna (k) and Sturla (o), have an area of more than $10 \mathrm{~km}^{2}$. Polcevera (l) has an area of more than $100 \mathrm{~km}^{2}$, while Bisagno $(\mathrm{m})$ has an area of slightly less than $100 \mathrm{~km}^{2}$. Finally, 10 other stream catchments range in area from 1 to $4 \mathrm{~km}^{2}$, and from west to 

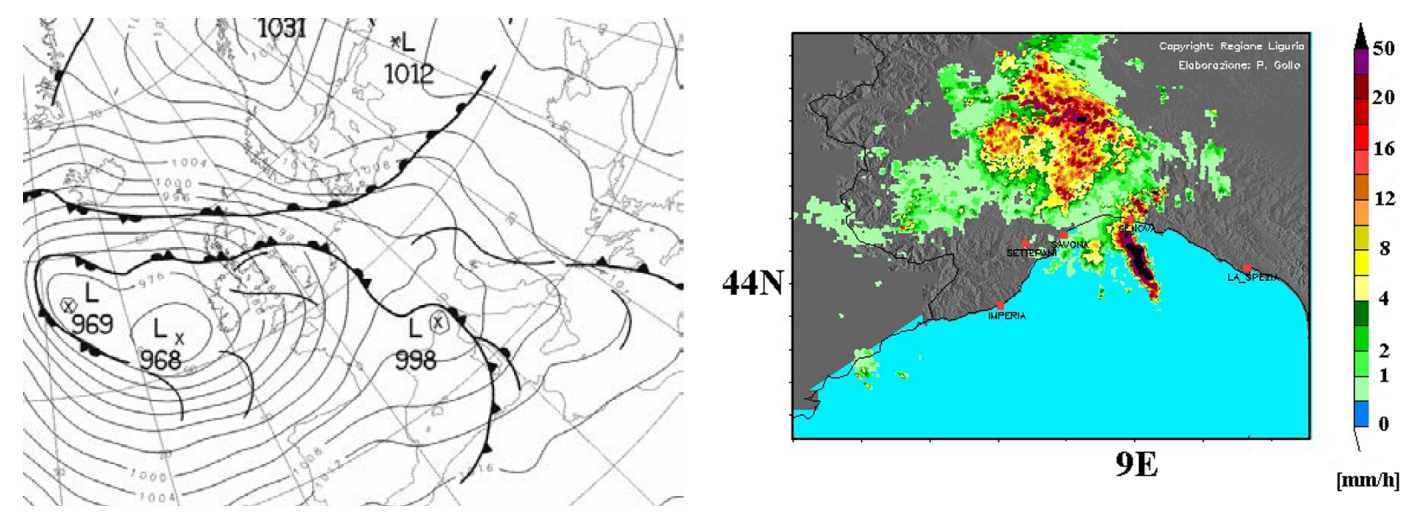

Figure 2. Isobars and fronts on the ground during a Genoa low (left panel). The convergence of currents coming from northerly and southerly sectors can create the formation of a thundery self-generating convective systems characterized by intense rainfall able to trigger flash floods (right panel).

east they are Vesima (a), San Michele (f), Sant'Antonio (g), Molinassi (i), Cantarena (j), Priaruggia (p), Castagna (q), Bagnara (r), San Pietro (s) and Murcarolo (t). There are over 10 other catchments with areas of less than $1 \mathrm{~km}^{2}$, most of them flowing directly into the old port which is located under the original historic amphitheatre of Genoa.

All these streams define floodplains only within the terminal sector near the estuary area.

Of all these catchments, the two most important are (1) the Polcevera stream which is the largest and the most populous basin $\left(140 \mathrm{~km}^{2}\right)$, located west of the historic amphitheatre, and (2) Bisagno stream $\left(95 \mathrm{~km}^{2}\right)$ flowing immediately to the east. Important urban areas are also located in the plain coastal basins of Leiro stream at Voltri $\left(27 \mathrm{~km}^{2}\right)$, of Varenna stream at Pegli $\left(22 \mathrm{~km}^{2}\right)$ and Chiaravagna stream at Sestri Ponente $\left(11 \mathrm{~km}^{2}\right)$.

Following an increasingly widespread practice in Liguria, many of the Genoa river beds are culverted (covered), sometimes for long stretches, especially the reaches towards the mouth. In these new narrow spaces, roads, parking areas and, in some cases, even homes, have been built.

The coastal climate is characterized by short and temperate winters (average in January $8^{\circ} \mathrm{C}$ ), temperate summers (average in July $24^{\circ} \mathrm{C}$ ) and widespread rainfall in all seasons, with the maximum occurring in autumn $(150-200 \mathrm{~mm}$ in October), an annual average ranging from 1100 to $1300 \mathrm{~mm}$ (Table 3 ) and an annual average temperature around $16^{\circ} \mathrm{C}$ (Italian Air Force, 2009; ARPAL, 2013). Overall, it is a humid temperate climate with a dry season restricted to 1 or 2 summer months.

The morphology of the Ligurian Gulf and the orographic barrier also contributes to rainy events which may be very intense, especially at the end of the summer or autumn when Atlantic perturbations may be blocked by the European continental anticyclone (Bossolasco et al., 1971; Faccini et al., 2005; Cevasco et al., 2010).
From a meteorological point of view, the Gulf of Genoa is characterized by a typical circulation referred to as the Genoa low which is also known as a Ligurian depression ("Genua Tief" in the central Alps). It is a cyclone that forms or intensifies from a pre-existing cyclone to the south of the Alps for orographic effect (Jansà, 1997; Jansa et al., 2014) over the Gulf of Genoa, Ligurian Sea. This cyclone generally remains stationary but sometimes can determine the weather of central Europe (Sáez de Cámara et al., 2011) or the Italian peninsula (Trigo et al., 1999) according to the "Vb" and "Vd" Van Bebber cyclone tracks (Bartholy et al., 2006). This secondary depression is linked to the arrival of the Atlantic perturbations behind the Alps and is formed on the Gulf primarily in the autumn, winter and spring periods (Anagnostopoulou et al., 2006). As a consequence, conditions of sharp thermodynamic contrast between hot humid Mediterranean air masses and cold air masses of continental origin are created. The cold air masses over the Po Plain and behind the mountainous Ligurian arc are redirected by the Genoa Low toward the centre of the Gulf, where they arrive at the ground through the mountain passes including the ones between Savona and Genoa, reaching modest altitudes, between 450 and $600 \mathrm{~m}$ above sea level (Fig. 2). Southern wet and warm air masses from the Mediterranean flow over these colder air masses. This typical circulation is responsible for the large amounts of rainfall distributed over the region surrounding the Ligurian Sea (Sacchini et al., 2012), in particular in the centraleastern sector of the region.

Of particular importance during times when hot humid flows coming from the Mediterranean Sea are associated with prefrontal situations preceding the arrival of Atlantic perturbations are the great contrasts between the air mass stationed over the warm Mediterranean Basin and the air masses moving from the Po Basin. The convergence of these air masses and the wind shear trigger the development of mesoscale convective systems (Silvestro et al., 2012). These convective systems have recently affected different locations 
Table 4. Impacts from the main geohydrological events in Genoa from 1970. Sources: Cati (1971); Bossolasco et al. (1971); Tropeano et al. (1993, 1995); Faccini et al. (2014, 2015a, b, c).

\begin{tabular}{|c|c|c|c|}
\hline $\begin{array}{l}\text { Date of major storm } \\
\text { event }\end{array}$ & Storm-related deaths & Damage losses* & Other damages \\
\hline 7 October 1970 & 44 fatalities (25 within Genoa) & EUR 19 billion & 1000 people homeless; 50000 people unemployed \\
\hline 27 September 1992 & 2 fatalities & EUR 125 million & 250 people homeless \\
\hline 23 September 1993 & 7 fatalities & EUR 800 million & $\begin{array}{l}100 \text { people homeless; impact on historic structures } \\
\text { and significant construction projects }\end{array}$ \\
\hline 4 October 2010 & 1 fatality & EUR 96 million & 20 people homeless \\
\hline 4 November 2011 & 6 fatalities & EUR 155 million & 150 people homeless \\
\hline 9-10 October 2014 & 1 fatality & EUR 250 million & 250 people homeless \\
\hline
\end{tabular}

* Original cost reported in current Euro.

over the Ligurian Gulf (Faccini et al., 2012), causing flash floods arising from rainfall intensities of over $500 \mathrm{~mm} / 6 \mathrm{~h}$ or $180 \mathrm{~mm} / 1 \mathrm{~h}$. The most recent of these events occurred on November 2014 in Genoa. These phenomena have been recurring and have been particularly violent in recent years, especially the last events that took place in Varazze and Sestri Ponente, Genoa, in 2010 (Faccini et al., 2015b), Cinqueterre (Cevasco et al., 2013; Buzzi et al., 2014) and Bisagno Valley, Genoa, in 2011 (Brandolini et al., 2012) and 2014 (Faccini et al., 2015a, c).

The rainfall amounts of the floods generated by local convective systems are unparalleled in the Mediterranean area: $948 \mathrm{~mm} / 24 \mathrm{~h}$ in Bolzaneto, Genoa, in the Polcevera Valley, north-west of the centre during the flood of 7-8 October 1970 and $181 \mathrm{~mm} / 1 \mathrm{~h}$ at Vicomorasso rain gauge, on the Genoa inland during the flood of 4 November 2011.

\subsection{Genoan geohydrological disasters in the last 50 years}

As described earlier, Liguria in general and Genoa in particular have been subjected to flood events due to the predisposing conditions of climate and urban morphology. Considering only the city of Genoa during the last 50 years, 10 important events took place, starting with the most dramatic one in 1970. Six of them caused very severe damage and casualties (Table 4) and they resulted from similar meteorological conditions. It is noticeable that the events that occurred in 1970 and 1993, which had affected a wider area, are those which suffered the greatest economic damages; while there were fatalities in all the episodes, with the largest number resultant of the disastrous flood of October 1970. The weather conditions in all these events were characterized by a blocking anticyclone to the east and a deep trough to the west (as described by Bossolasco et al. (1971) for the 1970 event), producing prefrontal storms on the warm branch of the perturbation (Faccini et al., 2014, 2015a, c). The following paragraphs describe the specific consequences of these six events.
The 1970 event in Genoa was also the most dramatic regarding damage and fatalities. On 7 October, prefrontal storms struck the western side of the city, then the centre and the hinterland the day after. The storms affected Voltri and Genoa before the arrival of the cold front. The heavy rainfall lasted more than $24 \mathrm{~h}$, with highs in Polcevera Valley. At Bolzaneto rain gauge, over $950 \mathrm{~mm}$ of rainfall in $24 \mathrm{~h}$ was measured. Over the city centre and the Bisagno Valley, $400 \mathrm{~mm}$ of rainfall was recorded in $24 \mathrm{~h}$. Cerusa, Leira, Varenna, Chiaravagna and Bisagno stream channels overflowed, submerging coastal areas and the city centre. In absence of discharge gauge stations, the maximum flow rate of the Bisagno stream was estimated by Cati (1971), near the Genova Brignole railway station, as $950 \mathrm{~m}^{3} \mathrm{~s}^{-1}$ $\left(12 \mathrm{~m}^{3} \mathrm{~s}^{-1} \mathrm{~km}^{-2}\right)$. The flow rate ensured by the Bisagno cover was approximately $700 \mathrm{~m}^{3} \mathrm{~s}^{-1}$. The maximum flow rate of the Polcevera stream, which barely remained within its banks, was estimated at $1656 \mathrm{~m}^{3} \mathrm{~s}^{-1}\left(12 \mathrm{~m}^{3} \mathrm{~s}^{-1} \mathrm{~km}^{2}\right)$.

On 27 September 1992, meteorological conditions like those of the 1970 event resulted in rainfall for $14 \mathrm{~h}$, with a cumulated amount of about $400 \mathrm{~mm}$. Sturla and Bisagno streams overflowed. The maximum estimated discharge of the Bisagno stream in 1992 was about $700 \mathrm{~m}^{3} \mathrm{~s}^{-1}$ at Castelfidardo bridge (Conti et al., 1994), located just upstream of the culverted stretch near the railway $\left(7.5 \mathrm{~m}^{3} \mathrm{~s}^{-1} \mathrm{~km}^{-2}\right)$. The Bisagno overflowed upstream of the cover under the Genoa Brignole railway station, flooding the historic district of Borgo Incrociati, the city centre around the neighbourhood of the Genoa Brignole railway station and the district called "Foce" (which means stream "mouth"). Fortunately, as soon as the stream overflowed, the rain stopped and damage was limited. Additionally, there were some fatalities near the mouth of the smaller adjacent Sturla creek that overflowed a few hours before (Fig. 1, catchment "o").

In 1993 on 23 September, with similar synoptic conditions, a new flood event occurred with rainfall amounts up to $350 \mathrm{~mm}$ in $5 \mathrm{~h}$ near Pegli (in Genoa, over $300 \mathrm{~mm}$ of rain in $15 \mathrm{~h}$ were recorded), which provoked the overflowing of Leiro stream (d) in Voltri, Varenna stream (h) in Pegli, 
S. Pietro stream (f) in Pra, Genoa, and tributaries of the Polcevera stream (d). Some criticalities affected the centre of Genoa in the historic amphitheatre, where several streams, totally or partially culverted, overflowed with a lot of damage, in particular the underpass under construction in Piazza Caricamento Square (near the Old Port and the current waterfront designed by the architect Renzo Piano). The rainfall event affected some basins that are not equipped with hydrometric rain gauge stations, so it is not possible to comment on the hydrological response of the watercourses.

During the severe event which occurred on 4 October 2010, the Mt. Gazzo rain gauge station (Sestri Ponente, Genoa) measured an hourly peak that exceeded $120 \mathrm{~mm}$ and cumulative rainfall of more than $400 \mathrm{~mm}$ over $6 \mathrm{~h}$ (Faccini et al., 2015b); the Chiaravagna stream overflowed and severely damaged the area near its mouth (Fig. 1 catchment "k"). Also the small adjacent Molinassi (i) and Cantarena creek (j) flooded the western part of the town of Sestri Ponente.

During the event of 4 November 2011, under the same meteorological configuration, the Vicomorasso rain gauge station (north Genoa) measured a rain peak of nearly $180 \mathrm{~mm} / 1 \mathrm{~h}$ and over $500 \mathrm{~mm} / 6 \mathrm{~h}$. This event struck in particular the Bisagno Valley and the catchment of Fereggiano creek, one of its small left tributaries. More than $500 \mathrm{~mm} / 6 \mathrm{~h}$ of water fell in this basin, with a peak of about $160 \mathrm{~mm} / 1 \mathrm{~h}$. The creek violently overflowed together with other small creeks just upstream of the Molassana area. The Bisagno stream, on the contrary, overflowed upstream of the beginning of the artificial cover, flooding the centre of Genoa. The peak discharge was estimated to be about $800 \mathrm{~m}^{3} \mathrm{~s}^{-1}$ $\left(8.7 \mathrm{~m}^{3} \mathrm{~s}^{-1} \mathrm{~km}^{-2}\right)$.

The most recent disastrous flood event of Genoa occurred on 9-10 October 2014, with a rainfall mechanism linked to the repeated "self-regenerating" thunderstorms, stationing for several hours over the city, which started in the warm prefrontal sector of the perturbation. Between 06:00 CET on 9 October and 12:00 CET on 10 October, on the basin of the river Bisagno some peaks of rain were recorded up to almost $140 \mathrm{~mm} \mathrm{~h}^{-1}$ and more than $550 \mathrm{~mm} / 24 \mathrm{~h}$, which resulted in a rapid increase in the level of all streams and subsequent flooding in the final stretch of the Bisagno stream. The maximum discharge estimated by flood markers was more than $800 \mathrm{~m}^{3} \mathrm{~s}^{-1}$. In Genoa also Sturla (o), Fereggiano, Noce (tributaries of the Bisagno stream) and Torbella creeks (tributary of the Polcevera stream) overflowed, so neighbourhoods west of the centre and east of the centre were inundated. All these events have impacted a narrow band of territory affected by a convective system as evidenced by the radar images and the isohyets of the event (Cati, 1971; Tropeano et al., 1993, 1995; Faccini et al., 2014, 2015a, c).

Other geohydrological events, even if less dramatic, which have occurred in Genoa since 1977, as well as the most significant in the Genoan metropolitan area, are shown in Table 5. These 14 additional events include five events involving only regular floods during the last 30 years of the 20th century and nine events during the first 14 years of the 21 st century, of which four were flash floods. Observations about geographical location, rainfall intensity and storm impacts related to these 14 events yield additional data useful in this analysis.

\section{Methods}

Flood risk is the result of two factors, hazards and vulnerability, and we analysed them both, considering (i) floods from the point of view of the recent increase of such events in the territory on the basis of observed climatic variations and (ii) the land vulnerability from the point of view of the territory modifications, above all increasing urbanization assessed by historical comparison of ancient and recent maps.

The present study depends greatly on historical documents; the authors incorporated research on past geohydrological events from both published and unpublished reports pertaining to the local area and undertook analysis of historic maps and urban studies to assess interaction with urban changes.

Historical sources have greatly contributed important documents in the reconstruction of areas exposed to the risks due to either the frequency or magnitude of geohydrological events (Glade et al., 2001; Luino et al., 2002; Tropeano and Turconi, 2004; Llasat et al., 2005; Hilker et al., 2009; Faccini et al., 2009; Porfido et al., 2009). Studies about past geohydrological events in Italy carried out by Consiglio Nazionale delle Ricerche (CNR, National Research Council) and by Servizio Idrografico e Mareografico Nazionale (SIMN, National Hydrographic and Tidal Service) (Cati, 1971; Cipolla et al., 1993, 1999; Tropeano et al., 1995) have been used to gather the most relevant information for the study area.

A number of authors have studied geohydrological hazards and recent increase thereof by analysing meteorological and climate factors and their interaction with the complex orography of Genoa and surrounding localities (Pasquale et al., 1994; Russo and Sacchini, 1994; Russo et al., 2000; Cevasco et al., 2010; Sacchini et al., 2012; Brandolini et al., 2012; Faccini et al., 2014, 2015a).

Climate factors were studied by analysing data from a data set composed of over 180 years of weather station measurements at the University of Genoa which is the historical reference for the Genoese town and applicable to Genoa.

The meteorological observatory of the Genoa University was established in 1832. The following year marked the beginning of observations and the seamless recording of data over time. In 1993, an automatic station was installed to replace the traditional mechanical one. It featured a full complement of electronic sensors for the detection of the basic parameters (rainfall, barometric pressure, air temperature and humidity, speed and direction of the wind and solar radiation). The automated station occupies the same location as its mechanical predecessor (on the flat roof of the historic 
Table 5. Other geohydrological processes in Genoa and main events in Genoan metropolitan area from 1977.

\begin{tabular}{|c|c|c|c|c|}
\hline Date & Locality & $\begin{array}{c}\text { Peak } \\
(\mathrm{mm} / 1 \mathrm{~h})\end{array}$ & $\begin{array}{l}\text { Rainfall } \\
\text { event } \\
\left(\mathrm{mm} \mathrm{h}^{-1}\right)\end{array}$ & Notes on the geohydrological event \\
\hline 6-8 October 1977 & $\begin{array}{l}\text { Genoa and } \\
\text { hinterland (Stura } \\
\text { Valley) }\end{array}$ & 109 & $405 / 72$ & $\begin{array}{l}\text { Geirato stream overflowed, middle Bisagno Valley } \\
\text { (Dagnino et al., 1978) }\end{array}$ \\
\hline 22 September 1992 & $\begin{array}{l}\text { Western metropolitan } \\
\text { area and Savona town }\end{array}$ & 92 & $523 / 24$ & $\begin{array}{l}\text { Damages of over ITL } 100 \text { billion (more than EUR } 50 \text { million) } \\
\text { (Cipolla et al., 1993; Tropeano et al., 1993) }\end{array}$ \\
\hline 23-25 September 1993 & $\begin{array}{l}\text { Genoa city centre and } \\
\text { Western metropolitan } \\
\text { area }\end{array}$ & 95 & $393 / 24$ & $\begin{array}{l}\text { Western basins (Varenna Valley), four fatalities in } \\
\text { inland areas (Tropeano et al., 1993) }\end{array}$ \\
\hline 4 November 1994 & $\begin{array}{l}\text { Western metropolitan } \\
\text { area }\end{array}$ & 87 & $211 / 24$ & $\begin{array}{l}\text { Western basins of Genoa (Varenna Valley) (Brandolini and } \\
\text { Ramella, 1994) }\end{array}$ \\
\hline 5-6 October 1995 & $\begin{array}{l}\text { Eastern metropolitan } \\
\text { area (Rapallo and } \\
\text { S. Margherita Ligure } \\
\text { cities) }\end{array}$ & 70 & $215 / 24$ & $\begin{array}{l}\text { Boate and San Siro streams overflowed (Faccini et al., } \\
\text { 2009) }\end{array}$ \\
\hline 6-23 November 2000 & $\begin{array}{l}\text { Genoa and } \\
\text { eastern Genoan } \\
\text { metropolitan area }\end{array}$ & 60 & $115 / 3$ & Lavagna Valley (Faccini et al., 2005) \\
\hline 24-26 November 2002 & $\begin{array}{l}\text { Genoa and } \\
\text { eastern metropolitan } \\
\text { area }\end{array}$ & 93 & $200 / 12$ & $\begin{array}{l}\text { Entella stream catchment (Faccini et al., 2005), } \\
\text { one fatality; some minor watercourses overflowed in the } \\
\text { Bisagno and Polcevera valleys }\end{array}$ \\
\hline 1 Jun 2007 & $\begin{array}{l}\text { Eastern metropolitan } \\
\text { area }\end{array}$ & 146 & $228 / 3$ & Recco stream catchments (Faccini et al., 2012) \\
\hline 4 October 2010 & $\begin{array}{l}\text { Western metropolitan } \\
\text { area and town of Varazze }\end{array}$ & 96 & $308 / 5$ & $\begin{array}{l}\text { Teiro stream catchment in Varazze, Chiaravagna } \\
\text { stream and all minor catchments in Sestri Ponente } \\
\text { (Faccini et al., 2015b) }\end{array}$ \\
\hline 25 October 2011 & Eastern Riviera & 143 & $468 / 6$ & $\begin{array}{l}\text { Vara Valley catchment, Monterosso and Vernazza } \\
\text { towns (Cinque Terre) (Cevasco et al., 2013) }\end{array}$ \\
\hline 21 October 2013 & $\begin{array}{l}\text { Eastern metropolitan } \\
\text { area }\end{array}$ & 87 & $187 / 3$ & $\begin{array}{l}\text { Entella stream catchment, collapse of the Carasco } \\
\text { bridge, two fatalities (Faccini et al., 2015c) }\end{array}$ \\
\hline 18-19 January 2014 & $\begin{array}{l}\text { Eastern metropolitan } \\
\text { area }\end{array}$ & 34 & $176 / 24$ & $\begin{array}{l}\text { Eastern Genoan basins and Poggio stream catchment } \\
\text { in Bogliasco, one fatality (Faccini et al., 2015c) }\end{array}$ \\
\hline 10-11 November 2014 & $\begin{array}{l}\text { Eastern metropolitan } \\
\text { area }\end{array}$ & 58 & $162 / 24$ & $\begin{array}{l}\text { Entella stream catchment, two fatalities (Faccini et al., } \\
\text { 2015c) }\end{array}$ \\
\hline 15 November 2014 & $\begin{array}{l}\text { Genoa western } \\
\text { metropolitan area and } \\
\text { inland }\end{array}$ & 52 & $290 / 12$ & $\begin{array}{l}\text { Upper Polcevera Valley, one fatality (Faccini et al., } \\
\text { 2015c) }\end{array}$ \\
\hline
\end{tabular}

palace which belongs to the Genoa University) at the geographic coordinates $44^{\circ} 24^{\prime} 55.04^{\prime \prime} \mathrm{N}, 8^{\circ} 55^{\prime} 36.53^{\prime \prime} \mathrm{E}$ ), with the barometric sensor at $58.3 \mathrm{~m}$ a.s.l. (above sea level).

The parameters are instantly detected by the sensors and transmitted to the acquisition unit which records the minimum and maximum values within the last 2 min and calculates the average value for the same time interval.

Prior to $1993, \operatorname{logs}$ were made of the observational data which were recorded at 08:00, 14:00 and 19:00 CET. The logs record the average, minimum and maximum measured for the parameters. These logs continue to be available.

Data relating to the cumulative annual rainfall, the average annual air temperature and the number of rainy days (rain measured exceeding $0.2 \mathrm{~mm}$ ) were extrapolated; the average value of rainfall intensity or rainfall rate $\left(\mathrm{mm} \mathrm{day}^{-1}\right)$ was obtained with the ratio between the total value of annual rainfall $(\mathrm{mm})$ and rainy days (number). 
The data were presented according to both their temporal dispersion (Begert et al., 2005) and through the application of the standardized anomaly index (SAI), which expresses the anomaly of the parameter examined compared to the mean value of the reference period (Coles, 2001). The index was calculated on an annual basis by averaging the standardized anomalies analysed for all parameters. In detail, the annual value of the SAI is obtained using the relation: (average annual value parameter-value parameter)/standard deviation parameter.

Then the presence of a possible trend was verified for (i) series more than 100 years old, (ii) annual cumulative rainfall $(\mathrm{mm})$, (iii) rainy days $\left(n^{\circ}\right)$, (iv) mean air temperature $\left({ }^{\circ} \mathrm{C}\right)$, and $(\mathrm{v})$ rainfall rate $\left(\mathrm{mm} \mathrm{day}^{-1}\right)$ using a Mann-Kendall statistical test at $95 \%$ of significance level. This was accomplished by applying the software "XLSTAT", to determine the percentage of reliability of the trend. The test was suggested by Mann (1945) and has been extensively used with environmental time series (Hipel and McLeod, 2005).

The features of the precipitation that caused flood events during the last 50 years were studied by analysing the maximum intensity rainfall recorded at Ponte Carrega rain gauge for $1,3,6,12$ and $24 \mathrm{~h}$, using the data available from the Hydrologic Annals and available from the current network of the ARPAL (Regional Agency for Protection of the Ligurian Environment). The Ponte Carrega rain gauge has been chosen for three reasons: (i) it is located in the middle of Bisagno Valley just $3 \mathrm{~km}$ from the instrument at Genoa University, (ii) it has recorded rainfall data since the end of the war, and (iii) the most significant flood events in the area of Genoa occurred in the basin of the Bisagno stream.

The rainfall intensity that caused the six flood events described in Sect. 2.2 have also been compared. To this end, the maximum rainfall recorded (for 1, 3, 6, 12 and $24 \mathrm{~h}$ ) at the rain gauge located closest to the most severe damage was selected. The average intensity was obtained by dividing the height of rainfall registered by the corresponding number of hours.

In order to assess the most important morphological changes within the area, in general, and the river network, in particular, a multi-temporal cartographic comparison of areas that are considered to be particularly significant was conducted. Special attention was given to changes in the vicinity to the active river bed and factors reflecting adequate quality and quantity of mapped data (Hargrove et al., 2006).

The study relied on maps produced after the annexation of the Republic of Genoa to the Kingdom of Savoy (1815). During the period 1815-1830, there was a map, "Gran Carta degli Stati Sardi di Terraferma", in use at 1:50000 scale, surveyed and produced by the Military Corps. For all the areas analysed, this historic map has been compared with maps produced afterwards by the Italian Military Geographic Institute IGMI (after Italian unification, 1861); specifically, the maps of 1878, 1907, 1923, 1934 and 1939 were used.
Finally, the recent Regional Technical Cartography (CTR by Regione Liguria Administration) mapped in 1980, 1994 and 2007 obtained by aerial snapshots and the Google Earth satellite have facilitated the comparisons of recent development.

Fixed historical points unchanged over time (natural elements, historical buildings, old bridges, monuments, etc.) were overlaid using ArcView GIS. This method enabled the determination of the principal urban changes that had occurred and facilitated goals such as measuring the width of the active riverbed at key locations.

\section{Results}

\subsection{Genoan climate and extreme event features}

As described previously, flood events with calamitous consequences have affected the Liguria region including Genoa with an apparent increase in their number and impact within recent decades (Tables 2, 4, and 5). In terms of their meteorological character, these events are all related to a blocking anticyclone setting up a prefrontal flow in the warm branch of the perturbation which generates convective systems, resulting in extremely intense and localized rainfall sufficient to generate flash floods (Fig. 2).

Figure 3 enables the distribution of the parameters relating to average annual air temperature, total annual rainfall, the number of rainy days and the rainfall intensity to be observed over time (almost 200 years).

The average annual air temperature varies from a minimum of $14.1^{\circ} \mathrm{C}$, detected in 1956 , to a maximum of $17.4^{\circ} \mathrm{C}$ in 1865 , with a mean value of $15.7^{\circ} \mathrm{C}$ and a standard deviation of $0.6^{\circ} \mathrm{C}$. The series shows cyclical fluctuations and a significant increase in time.

The total annual rainfall has a minimum value of $543 \mathrm{~mm}$, recorded in 1921, and a maximum of $2774 \mathrm{~mm}$ recorded in 1872 , with the average value of $1,272 \mathrm{~mm}$ and a deviation of $317 \mathrm{~mm}$. The series fluctuates around its average value, with no significant visible changes over time.

Rainy days show a minimum of 58 in 1921 and 2006, and a maximum of 160 in 1872, with an average of 101 days of rain per year and a deviation of 19 days. The series shows a clear decrease in time, passing from a medium value of 120 days in the first half of the 19th century to a medium value less than 100 days in the last 30 years.

The rainfall rate, calculated as the ratio between the annual rainfall and the number of rainy days, shows a significant increase over time and a greater dispersion of data in the last 50 years, linked to the similar dispersion of the total annual rainfall.

Four data series described above are considered very informative because they are based on a long time series collected by measurements at the same place which has not experienced significant urban change in the neighbourhood. A 

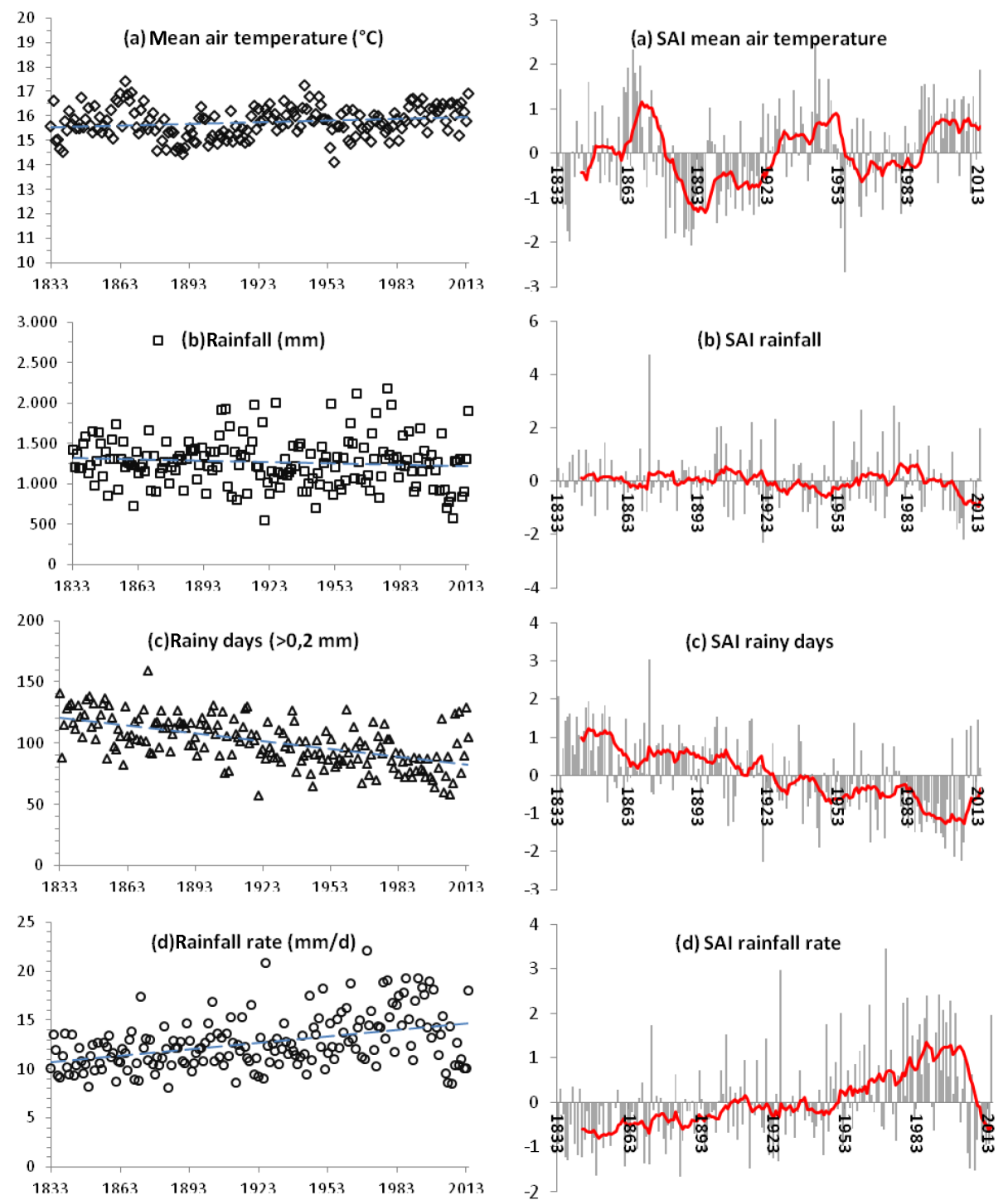

Figure 3. Climate series of annual rainfall, average annual air temperature, rainy days and rainfall rate in Genoa University weather station from 1833 to 2014. In the right column, the standardized anomaly index data are shown.

Mann-Kendall test has been applied to them in order to assess the presence of a statistically significant trend (Table 6). The average annual air temperature shows a $99 \%$ rising trend $\left(+0.146^{\circ} \mathrm{C} \mathrm{yr}^{-1}\right)$, the annual rainfall shows a $90 \%$ decreasing trend $\left(-0.08 \mathrm{~mm} \mathrm{yr}^{-1}\right)$, rainy days show a $99 \%$ decreasing trend $\left(-0.4311\right.$ day $\left.^{-1}\right)$ and the rainfall rate shows a $99 \%$ increasing trend $\left(+0.277 \mathrm{~mm} \mathrm{yr}^{-1}\right)$.

In regard to processing the four series of parameters according to the standardized anomaly index (SAI), it is possible to observe (Fig. 3) several factors: (1) the annual average temperatures show at least five oscillations of higher order with values that have become positive since the 1920s, (2) the total annual rainfall have only small fluctuations around the average value, with values predominantly negative in the third millennium, (3) rainy days show a clear decrease steady over time, with positive values until the 1920s and predominantly negative values in the following years, and (4) the average intensity of daily rainfall shows a steady increase, with positive values mainly from the 1920 s and a marked decrease in the last decade.

Figure 4 shows the rainfall intensity $\left(\mathrm{mm} \mathrm{h}^{-1}\right)$ in time $(\mathrm{h})$ for the events which struck Genoa in 1970, 1992, 1993, 2010, 2011 and 2014 (top left) and the series of the annual rainfall peaks through 1, 3, 6, 12, $24 \mathrm{~h}$ directly in the middle of Bisagno Basin (Ponte Carrega rain gauge).

It is possible to observe that the events during the 20th century show greater rainfall intensity for precipitation of shorter duration $(1,3$ and $6 \mathrm{~h})$, and intensity similar to the events of 1970, 1992 and 1993 for 12 and $24 \mathrm{~h}$. 
Table 6. Mann-Kendall test statistic.

\begin{tabular}{lllll}
\hline & $\begin{array}{l}\text { Annual } \\
\text { rainfall }\end{array}$ & $\begin{array}{l}\text { Rainfall } \\
\text { rate }\end{array}$ & $\begin{array}{l}\text { Mean } \\
\text { air temperature }\end{array}$ & $\begin{array}{l}\text { Rainy } \\
\text { days }\end{array}$ \\
\hline$\tau$ Kendall & -0.080 & 0.277 & 0.146 & -0.431 \\
Score & -1214 & 4436 & 2365 & -6876 \\
Var $(S)$ & 664268 & 664270 & 664221 & 663988 \\
Two-sided $p$ value & 0.111 & $<0.0001$ & 0.004 & $<0.0001$ \\
$\alpha$ & 0.05 & 0.05 & 0.05 & 0.05 \\
Trend & no trend & positive & positive & negative \\
\hline
\end{tabular}
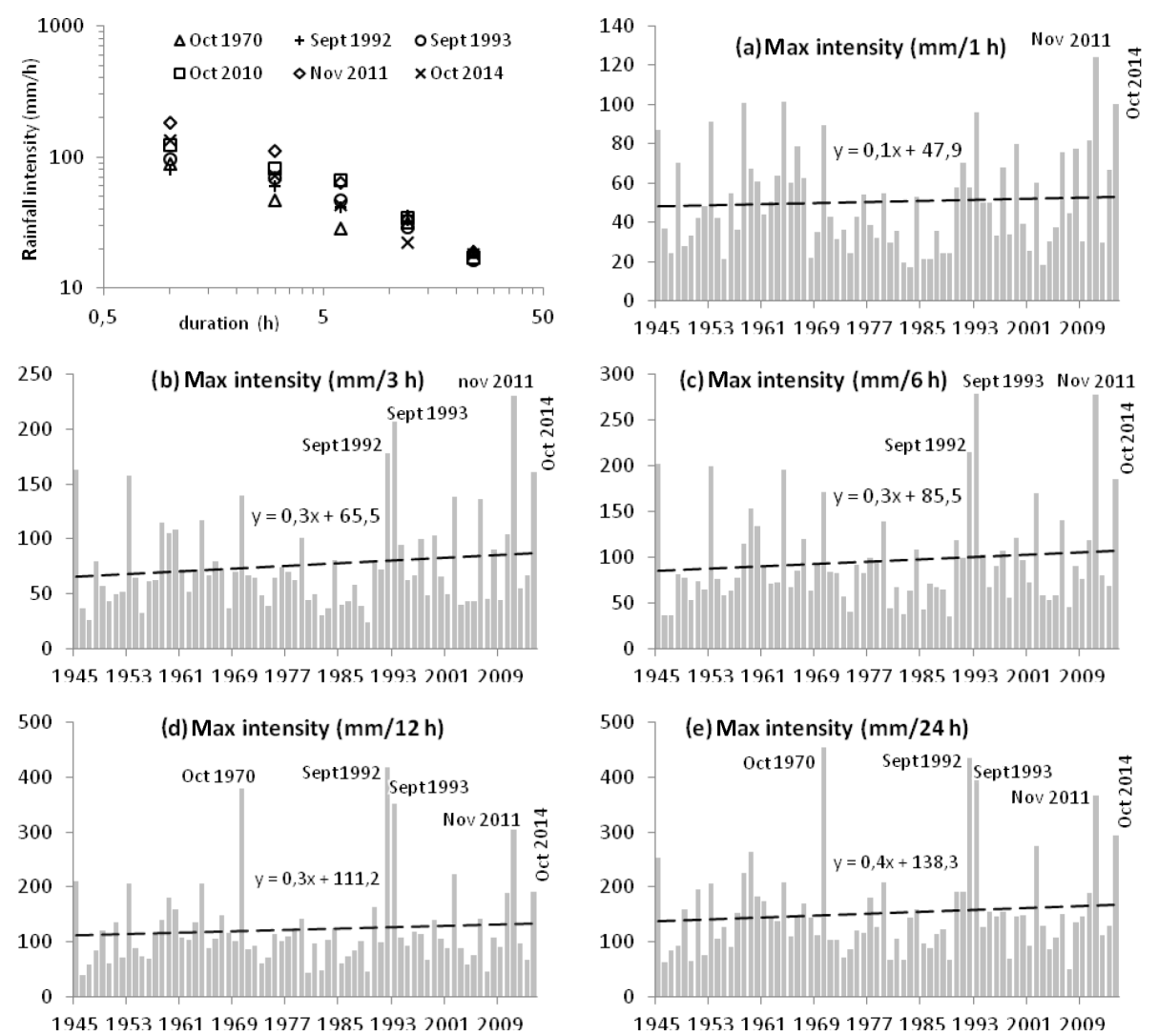

Figure 4. Rainfall intensity $\left(\mathrm{mm} \mathrm{h}^{-1}\right)$ vs. time (h) recorded at the rain gauge located closest to the most severe damage surveyed for 1,3 , 6, 12 and $24 \mathrm{~h}$ for the events that occurred in 1970 (Bisagno), 1992 (Bisagno), 1993 (historical centre and Varenna), 2010 (Chiaravagna), 2011 (Fereggiano-Bisagno) and 2014 (Bisagno). Maximum annual rainfall for 1, 3, 6, 12 and $24 \mathrm{~h}$ at the Ponte Carrega rain gauge (middle Bisagno Valley); the main floods are depicted.

The annual series of maximum rainfall at $1,3,6,12,24 \mathrm{~h}$ show a positive linear regression, although not showing statistical significance. In a period of 12 and $24 \mathrm{~h}$ the peaks relating to the floods of 1970, 1992, 1993, 2011 and 2014 are highlighted in particular; the event of 2010 is not highlighted because its downpour centre occurred at Sestri Ponente, in the west of Genoa. Regarding 3 and $6 \mathrm{~h}$ the peaks of 1992 , 1993, 2011 and 2014 are highlighted. For maximum hourly rainfall only the peaks of 2011 and 2014 are evidenced.

It is possible to notice that in the events of the 20th century, the same rainfall amount was attained in a shorter time. In the Bisagno Basin, more than $400 \mathrm{~mm}$ was recorded in $24 \mathrm{~h}$, during October 1970, approximately the same value, but in $15 \mathrm{~h}$ in September 1992 and up to more than $500 \mathrm{~mm}$ in only $8 \mathrm{~h}$ in October 2011 and 2014.

Figure 5 shows a hyetograph and hydrograph related to events from 1970 to 2014 through which we can observe the rapid response between the impulse rainfall and the flood $(3 \mathrm{~h}$ for Bisagno stream, $4 \mathrm{~h}$ for Polcevera stream). It is also possible to note that the peaks of the hyetograph are more concentrated in the events which occurred in the 21st century. The high intensity within periods of longer duration rainfall 

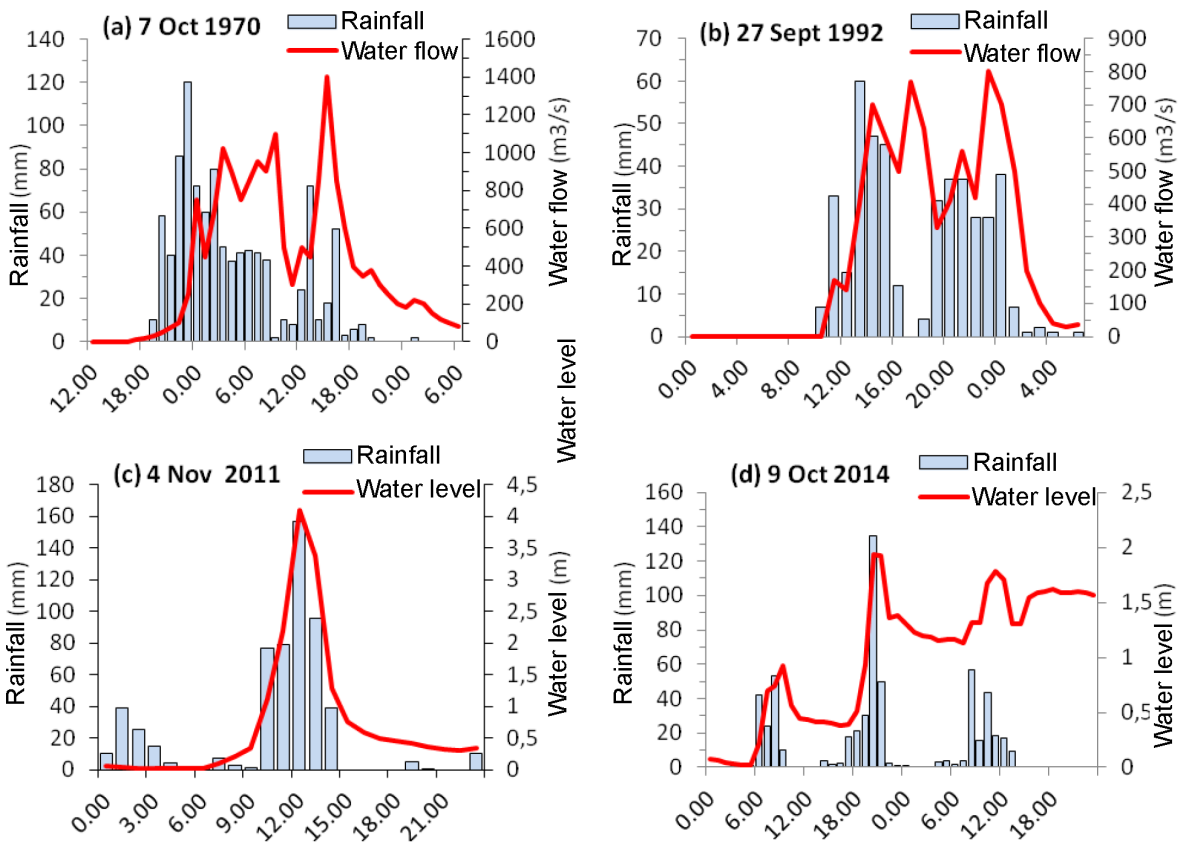

Figure 5. Rainfall vs. water level for the events of 1970, 1992, 2011 and 2014: (a) Polcevera at Bolzaneto in 1970, (b) Bisagno at final culvert in 1992, (c) Fereggiano-Bisagno in 2011, (d) Geirato (middle Bisagno) in 2014

caused many problems for the basins larger than $10 \mathrm{~km}^{2}$. In the Bisagno and Polcevera basins, a more complicated response was observed on the hydrographic network, characterized by multiple bursts distributed in different temporal periods, presumably with different temporal influence on the sub-basins.

The high intensity of precipitation of short duration creates problems, especially in the basins with areas of less than $10 \mathrm{~km}^{2}$ (e.g. Fereggiano creek, and neighbouring Noce and Rovare creeks), causing flash-flood phenomena with a practically instantaneous time of response.

\subsection{Genoan urban development}

Analysing many maps of the Republican Age (from 10th century to 1815) we can observe that Genoan urban development was limited to the hills surrounding the ancient natural harbour which is the actual historical centre. Connecting valleys and areas further inland were populated only by small villages and narrow trade routes, while the city, surrounded by walls for military defence, was open only to the sea. A number of small channelled streams flow towards the harbour and there is historical information that indicates some hydrological problems (during the years of 1222 and 1407 in particular). Since the annexation of the Republic of Genoa to the Kingdom of Savoy (1815) new roads were built, triggering urbanization of surrounding valleys where the majority of citizens live in the present day.

As examples valid for the whole Ligurian context, the urban growth in Genoa of Bisagno Valley, Polcevera Valley and of Sestri Ponente (2010 flood) are shown in Figs. 6-8. Using old maps it is possible to observe the gradual occupation of the fluvial plain, which started in the 19th century and which was completed after the World War II. The building numbers have increased from 65000 in 1861 to 305000 today, while the population in the area of the present Genoa Municipality rose from about 240000 inhabitants (1861) to a maximum of 850000 in the early 1970s (Fig. 9). The urbanization of the hills still continued in the 1980s and 1990s after the full urbanization of the floodplain.

The geohydrological problems related to Genoan urban development can be grouped into four main geomorphological-environmental issues:

i. modifications in land use, changing it from predominantly agricultural to urbanized (Fig. 9), particularly with the complete urbanization of the plain and the covering of the watercourses (Disse and Engel, 2001; Nirupama and Simonovic, 2007; Luino et al., 2012; Luino, 2014);

ii. variations in the flood channel width of the streams with a narrowing of the effective discharge section (Corominas and Alonso, 1990; Baioni, 2011; Faccini et al., 2014);

iii. progradation of the coastal plain towards the sea with new embankments and urbanization (Petrucci et al., 2012; Kellens et al., 2013; Faccini et al., 2015a); 

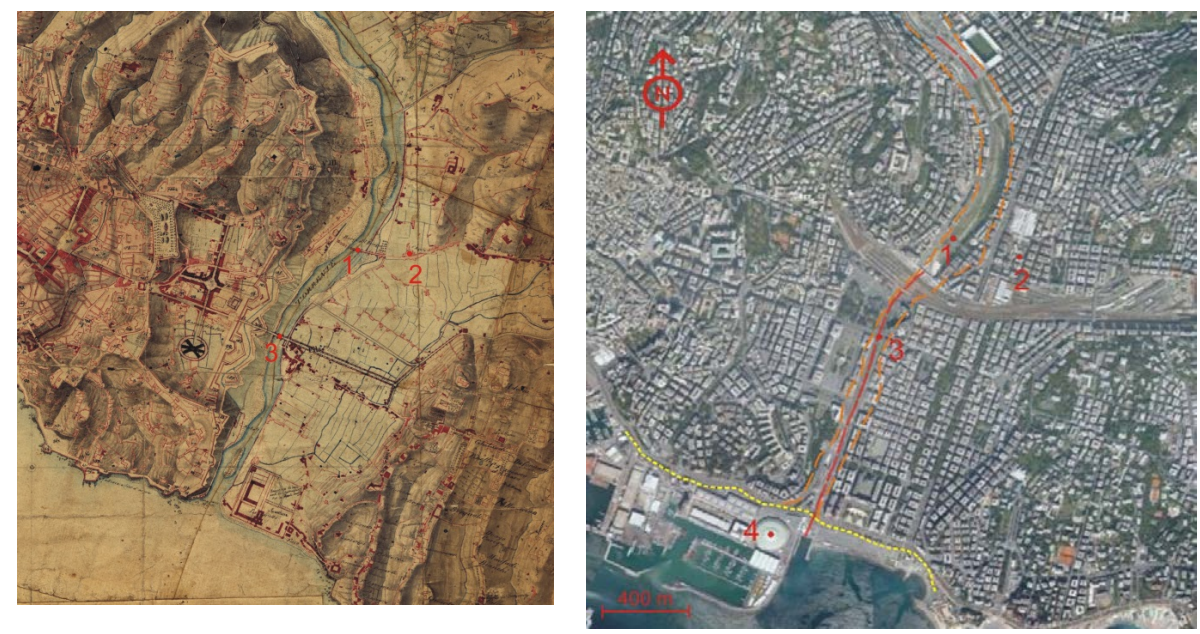

Figure 6. Final stretch of the Bisagno stream at the beginning of the 19th century (left panel) and in the present day (right panel). Note the complete urbanization, the progradation to the sea in Piazzale Kennedy area and Fiera del Mare (4) and the narrowing of the flow section near S. Agata bridge (1) and of Pila bridge (S. Zita) (3). Number 2 shows the Sant'Agata Cloister, where the left pier of the bridge rose (280 m length). Note that the stream has been completely culverted downstream from the railway since the 1930s (red dashed line). The orange dashed line indicates the Bisagno stream banks at the beginning of 1800; the yellow dashed line indicates the shoreline at the beginning of the 19 th century.
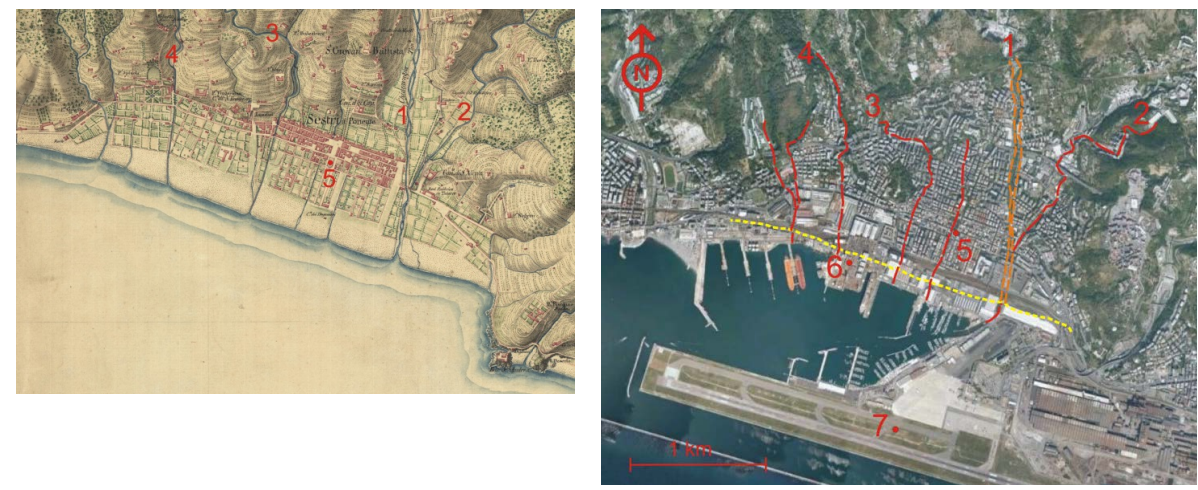

Figure 7. Comparison of the final stretch of the Chiaravagna stream 1821 and today. Note the urbanization of the plain, shipyards (6), the old small harbour and the airport (7) and the railway. It is possible to observe the strong progradation to the sea, the covering of the Chiaravagna stream (1), whose banks are indicated by a dashed orange line, and the Rio Ruscarolo creek (2), whose deviation has directed its flow into the Chiaravagna stream and not to the beach. Numbers 3 and 4 indicate the Molinassi and Cantarena Streams (dotted red), number 5 is the Church of N. S. dell'Assunta in the historic centre of Sestri Ponente. The dashed yellow line indicates the shoreline at the beginning of the 19 th century.

iv. total diversion of the natural riverbed and concentration of surface runoff in new more restricted areas (Faccini et al., 2015b).

In order to exemplify the anthropic changes related to these four issues (see Fig. 1 for location), the maps of the Gran Carta degli Stati Sardi di Terraferma (1816-30) have been used, comparing them with the current situation shown by the Google Earth maps for (1) the end stretch of the Bisagno stream, (2) the town of Sestri Ponente on the Chiaravagna stream, (3) the final stretch of the Polcevera stream and (4) its valley stretch near Bolzaneto. These lands were autonomous municipalities in the past and then they were incorporated into the Genoa municipality starting from 1873 (end stretch of the Bisagno stream) and in 1926 (Polcevera Valley, Sestri Ponente and the rest of the present municipality) under the fascist dictatorship.

\subsubsection{Variations in land use}

The Bisagno Basin can be considered as a key watershed for the analysis of changes in land use. Figure 6 shows the areas on the Bisagno stream valley floors, but similar patterns of change could be made for all the coastal plains of the municipality of Genoa, from Voltri to Nervi, and also for all the 

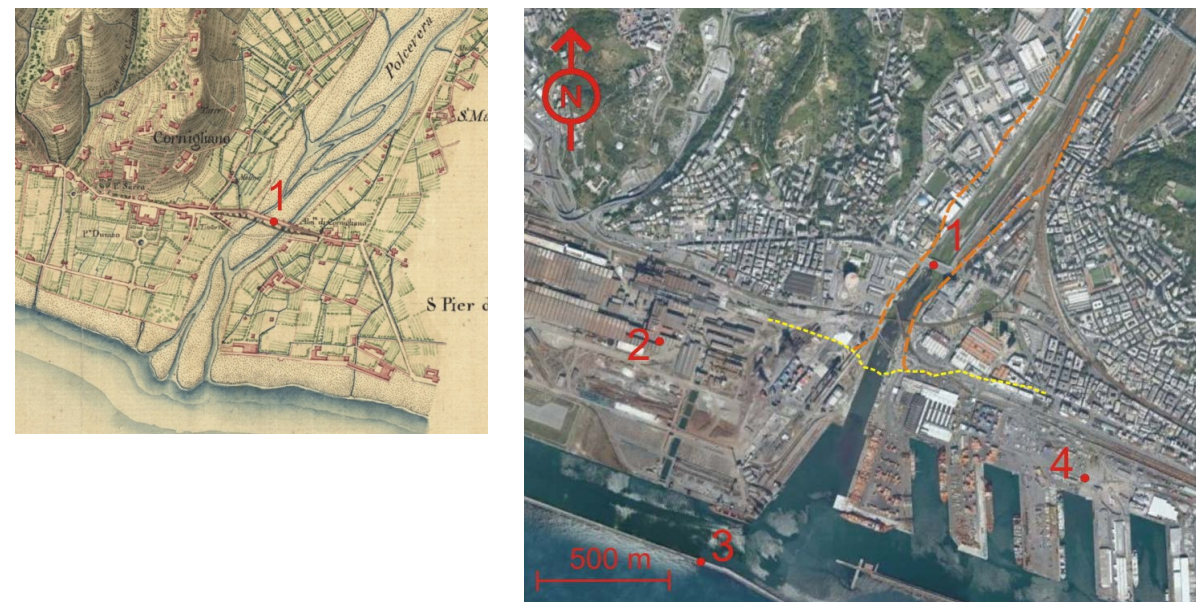

Figure 8. Final stretch of the Polcevera stream: 1821 (left panel) and today (right panel). The change in land use on the coast is noticeable the strong narrowing of the stream flow section, the reduction of the Cornigliano bridge (1), the urbanization of the plain, the steelworks (2), the Sampierdarena harbour (4), the barrier in the sea (3) and the impressive progradation towards the sea. It is also important to observe that the watercourse with braided facies has been reduced to a channel. Orange dashed lines indicate the slope of the Polcevera stream at the beginning of the 19th century; the yellow dotted line marks the shoreline in the same period.

major coastal towns of Liguria. The whole final stretch of Bisagno stream is culverted downstream parallel to the railway (Fig. 10); the length of the main watercourse in the plain area is about $12 \mathrm{~km}(24 \mathrm{~km}$ in total), of which $0.3 \mathrm{~km}$ totally culverted just on the flank of the Genoa football stadium and $1.4 \mathrm{~km}$ is covered between the railway and the mouth. While the land use in the basin shows a relevant decrease of wooded areas in the last 2 centuries and a progressive increase of the urbanized surfaces, particularly near the mouth (Fig. 9), the growth of the Genoan population occurred when the urban pressure began in the plans of streams; the Bisagno plain, unfortunately, is probably one of the worst examples at a Mediterranean level.

The Polcevera Valley (Fig. 8) and particularly its final stretch and the district of Sestri Ponente (Fig. 7) have suffered the gradual and complete urbanization of the valley floors; first in the middle of the 19th century, when such strategic areas located near the sea were the subject of the first industrial settlements that allowed the Italian industrial development; then further extension was pursued with residential building, public housing, facilities and road infrastructure. Among the Polcevera Valley and Sestri Ponente (Fig. 8 west Polcevera stream) it is possible to observe an area still occupied by a steelworks built in the 1950s over a large beach area and, now, partially abandoned and demolished.

\subsubsection{Modifications in the width of riverbed}

The Bisagno riverbed has undergone a significant constriction in channel width in the last two hundred years. Comparing the 1830 map and a recent aerial photograph, it is possible to note that the St. Agata medieval bridge, built along the ancient Roman road, changed approximately from $280 \mathrm{~m}$ wide to the current $70 \mathrm{~m}$ (Fig. 6). The bridge was repeatedly damaged and almost destroyed during the floods of 1970 and 1992. Near the present city centre, the so-called Pila bridge, which crossed a $120 \mathrm{~m}$ wide channel at the beginning of the 19th century, is now constricted by the complete covering of the Bisagno stream which was constructed in the 1930s, with a width of about $50 \mathrm{~m}$; while at the mouth ("Foce") the width was reduced from about $200 \mathrm{~m}$ (early 19th century) to the present $50 \mathrm{~m}$. Similarly in the Polcevera Valley, the bridge of Cornigliano, on the ancient Roman "Via Aurelia di Ponente", passed over a channel of about $150 \mathrm{~m}$ in width at the beginning of the 19th century but has been reduced to its present width of $75 \mathrm{~m}$ (Fig. 8).

\subsubsection{The progradation of the coastline to the sea}

In Fig. 8 at the mouth of the Polcevera, we can observe the progradation of the coastline to the sea, completely due to the filling of the seaside to create flat surfaces for industrial activities. The complete banking of the stream is noticeable, as well as the new roads on the banks built in the 1990s and the commercial centre of Fiumara, close to the stream's mouth, built in the 2000s in place of abandoned steel and engineering industries. Situated on the left bank, moreover, the works related to the Genoa Sampierdarena container harbour, the piers and the breakwater dam.

With respect to Sestri Ponente (Fig. 7), in around 11th century, the sea flowed into the Chiaravagna Valley through the small San Lorenzo Gulf and a small harbour was located at the base of the hills. In 1238 the sea reached the root of the present marine terrace, while in the 17th century the sea flowed up to the main Church of the Assunta, whose portal 


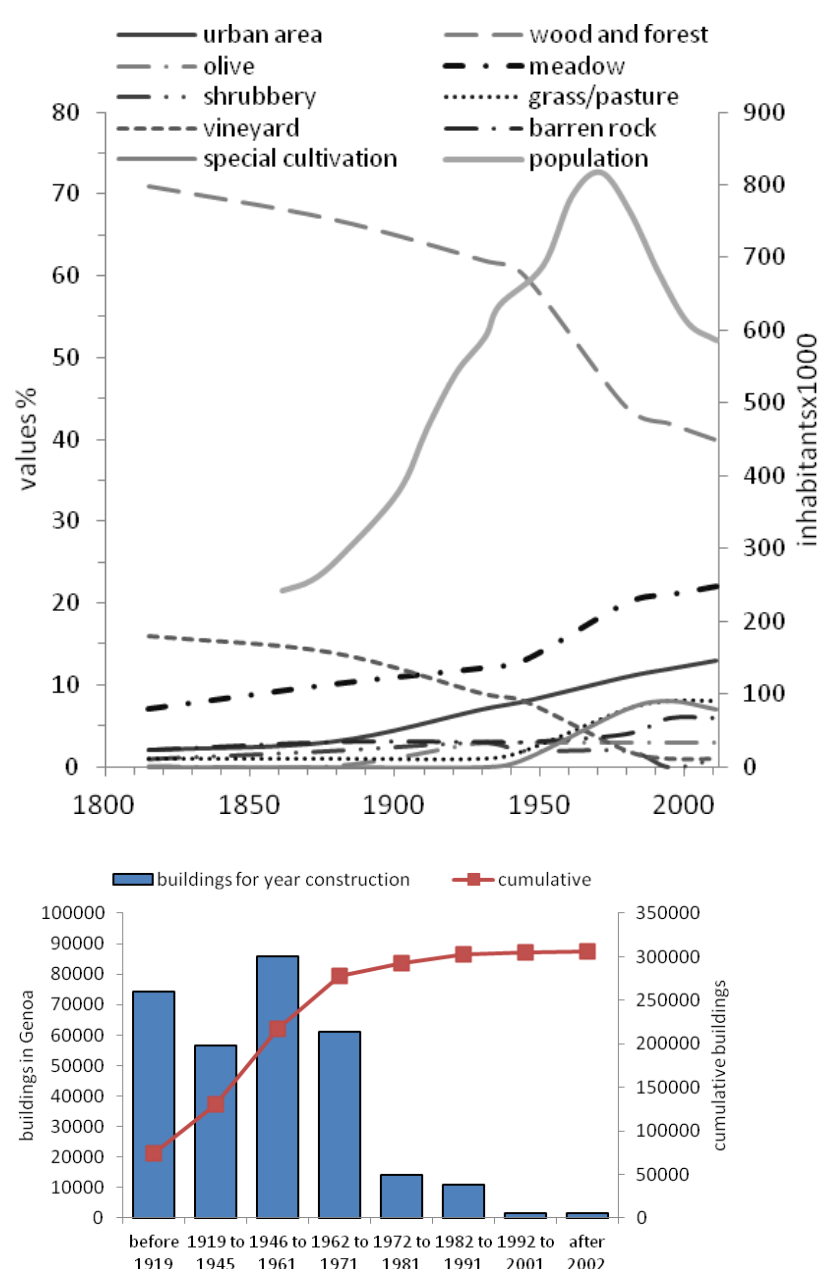

Figure 9. Land use trend in the Bisagno stream basin (area of about $95 \mathrm{~km}^{2}$ ) from 1800 to the present day, and Genoa's population since the birth of the Italian Kingdom until the present day (top); the number of buildings in Genoa from the end of the First World War to the present day, from ISTAT (2011) (below).

is, in effect, facing upstream. The church was built on the seaside and it is $1 \mathrm{~km}$ away from the sea in the present day. These details show that the area has been affected by progradation of the alluvial plain since historical times. In addition to this natural trend, anthropogenic factors contributed to the enlargement of the plan. In the second half of the 19th century, a seashore railway was built which facilitated the plain becoming completely urbanized in the 20th century. Additionally, the shipyards, which were developed mainly in the 1930s, and Genoa Cristoforo Colombo Airport, constructed in the 1960s, resulted in the final separation of the town from the sea by cyclopean embankments and the curving of the streams. Consequently, historical floods occurred mainly in the 20th century, with the historical analysis identifying some major floods linked to strong meteorological events at Sestri Ponente in 1900, 1906, 1911, 1929, 1945, 1951, 1970, 1977, 1993 and 2010.

\subsubsection{The riverbed diversion}

Urbanization in this area has included riverbed diversion. Inland at Bolzaneto, the passage of the railroad GenoaTurin (1854) entailed the cutting of a meander of the Polcevera (Fig. 11).

A new riverbed was excavated and displaced about $300 \mathrm{~m}$ towards the west with a narrower discharge section about $60 \mathrm{~m}$ less than the original situation. The abandoned meander was filled in with debris dug from the railway tunnels; such a filled riverbed has been used as a preferential settlement for Bolzaneto district expansion (once an autonomous municipality).

In Sestri Ponente (Fig. 7) we can observe the Ruscarolo stream diversion. It does not flow naturally into its urbanized beach anymore, but is displaced $400 \mathrm{~m}$ parallel to the seashore. This was accomplished by artificially diverting the Ruscarolo into the Chiaravagna stream without channel adjustment to accommodate the new discharge.

\section{Discussion and conclusion}

Considering the historical analysis and the wealth of historical information and measurements available since the 19th century it is clear that the frequency of significant damaging events has increased in recent times. In Genoa, their recurrence has increased from two events during the span 1800-1950 to six events between 1951-2000 and to four events during the first 14 years of the 21 st century (Fig. 12).

The annual average temperature shows a clear growth according to recent climate change trends (Fig. 3). The total annual rainfall shows a slight decrease that is not statistically significant, but appreciable. The rainfall rate shows an increasing trend, while the number of rainy days per year is decreasing, according to the previous studies of Pasquale et al. (1994) and Russo et al. (2000). Cortemiglia (2006) had observed that in the Genoese historical series the maxima of rainfall for several consecutive days is on the increase, as well as the number of days without precipitation. The data therefore support the fact that rainfall is concentrated in shorter periods. It is noteworthy that for significant autumnal floods, the rainfall over a few hours can be greater than monthly rainfall that commonly falls in the autumn months.

Recently, in opposition to the trend of the last century, a slight increase of the number of rainy days, a decrease in annual rainfall and a decrease in the annual precipitation rate have been observed. That means that it more often rains with moderate intensity, except for the occasional very intense thunderstorms which have decreased. This change seems related to a recent decrease in the number of Genoa lows occurring in the Gulf of Genoa due to the tropical air expansion towards the north, which causes less annual rainfall, but not a decrease in rainy days (Anagnostopoulou et al., 2006). 

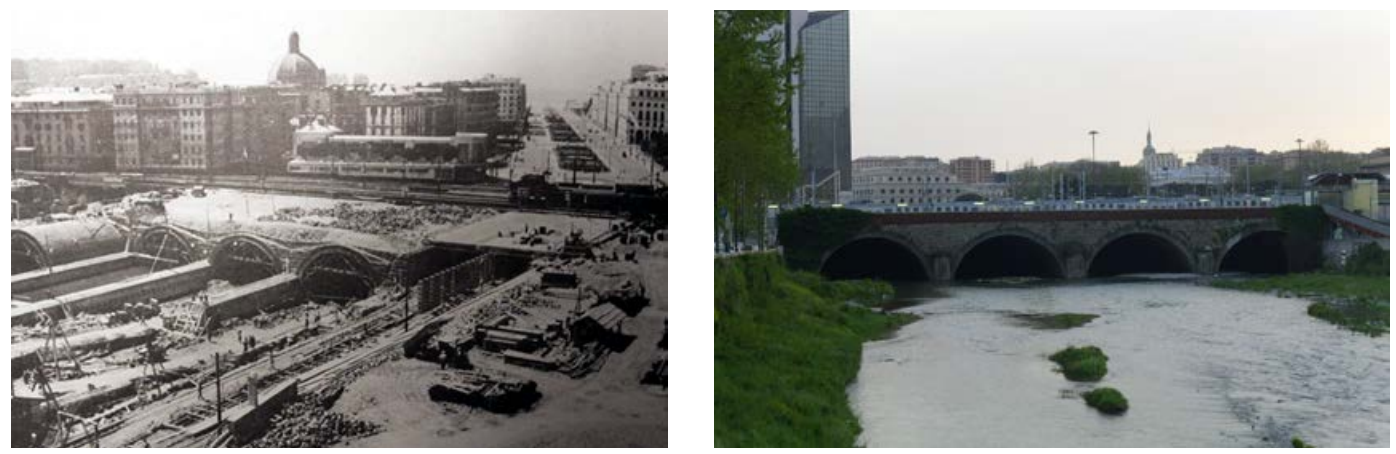

Figure 10. The Bisagno stream culvert during its construction (1930) and in the present day.
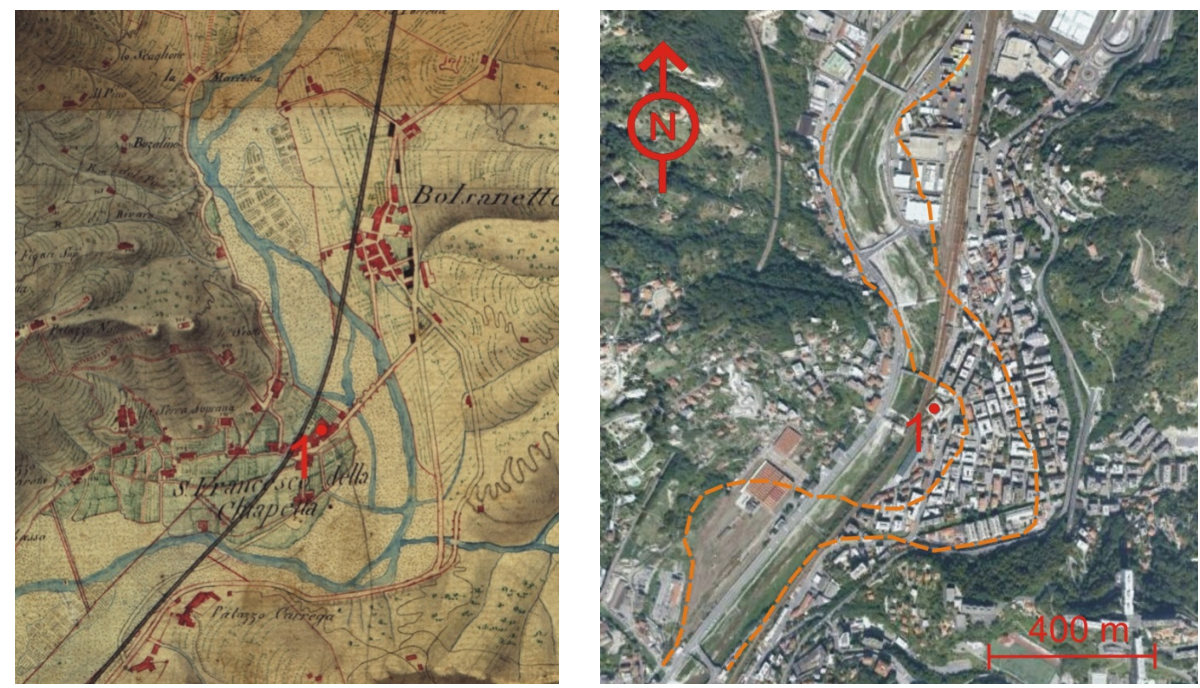

Figure 11. Bolzaneto urban area in the medium stretch of Polcevera stream at the beginning of the 19th century (left panel) and today (right panel). Number 1 denotes the San Francesco Friary; until the second half of the 19th century the church was located on the right bank, on the inside of a large bend. When the Genoa-Turin railway was constructed (black line) the Polcevera riverbed was straightened and embanked, removing its bend. A new riverbed was dug, $500 \mathrm{~m}$, cutting the foot of the Murta Hill; so the San Francesco Friary is located on the left bank in the present day. The narrowing of the useful section of the flow stream, whose banks are indicated by the orange dotted lines in the present aerial photograph, is evident. The largest part of the abandoned meander is occupied by the populated centre of Bolzaneto.

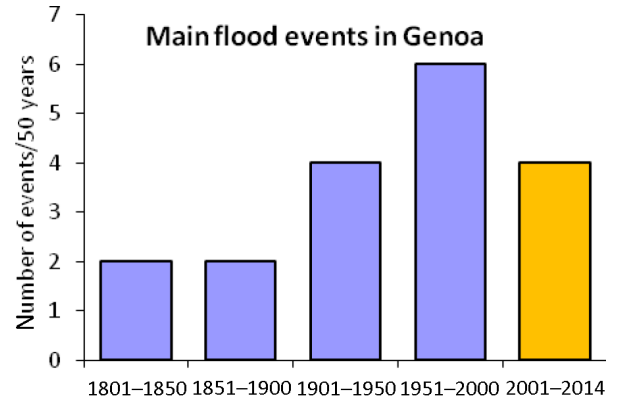

Figure 12. Semi-centennial distribution of the most important flood events in Genoa since 1801. In the present millennium, four events have occurred in only 14 years.
The increased risk posed by the greater frequency of intense rainfall events may be evaluated not only in terms of casualties, but also in terms of goods potentially exposed to the floods. Using the historical maps of the last 2 centuries, it is possible to note a remarkable increase in urbanization in the alluvial plains along the riverbeds, a general narrowing of the watercourse's flow section, some examples of original riverbeds subsequently artificially diverted and a general progradation towards the seaside of the coastal plain, due to man-made embankments, for further urbanization. In many places these situations create very high vulnerability compared to historic conditions. Additionally, the progressive urbanization of floodplains and hills, accompanied by a marked increase in population and infrastructure, leading to the reduction of flow sections, soil waterproofing and a rise 

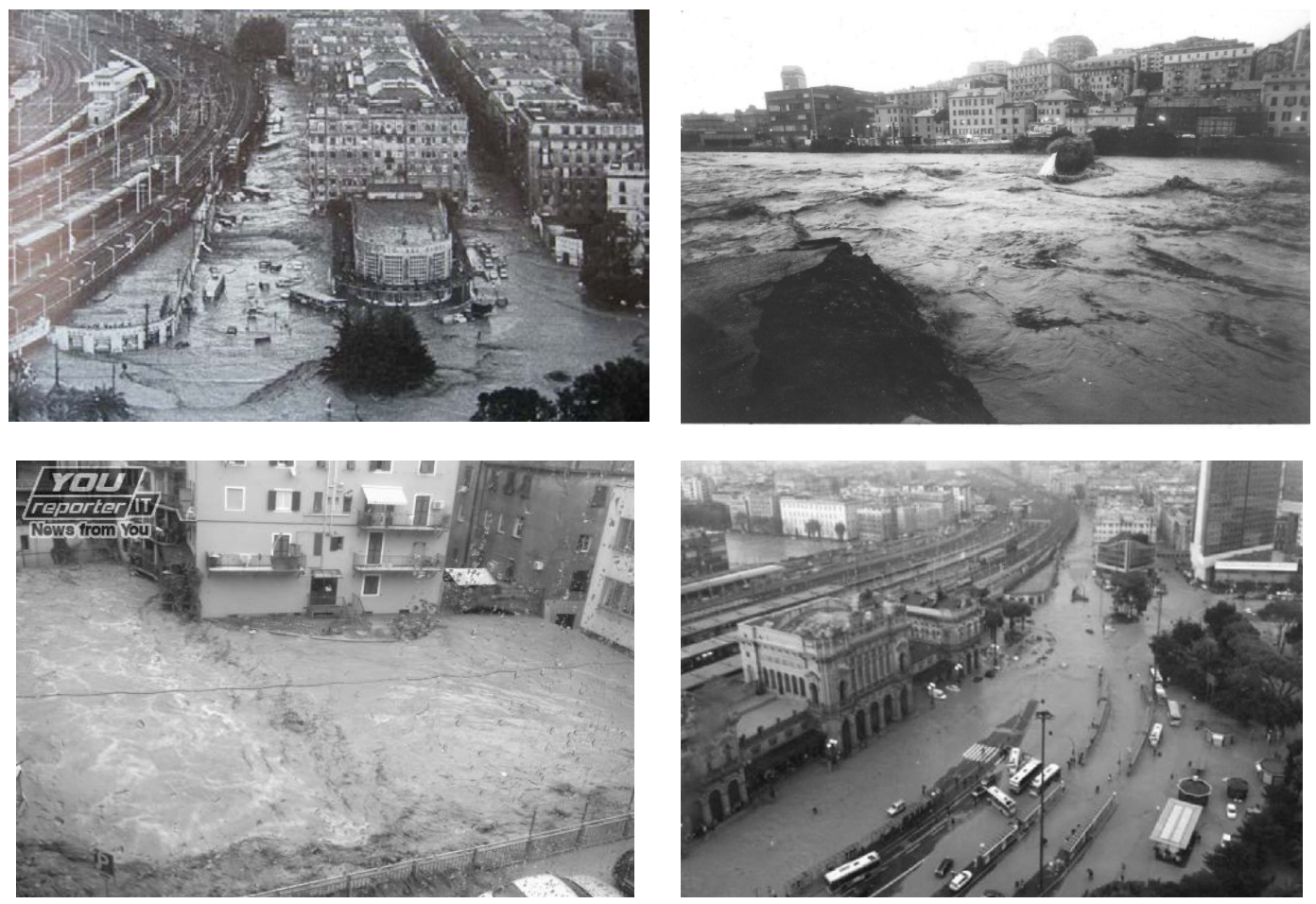

Figure 13. Inundations in Genoa: some dramatic photographs of different flood events. Top left: October 1970 - Bisagno overflowing in the zone downstream the covering near the Genoa Brignole railway station; top right: September 1992 - the swollen waters of the Bisagno destroyed some arches of the Sant'Agata bridge, which had already been damaged in 1970; bottom left: October 2010 - Chiaravagna's inundation in Sestri Ponente; bottom right: November 2011 - Genoa Brignole railway station inundated again (compare with top left).

in runoff velocity, also results in a prominent reduction in the times of concentration together with the greater vulnerability (King et al., 2005, Figs. 6-8).

Consequently, the geohydrological risks, determined by the result of hazards and vulnerability, are progressively raised because of climatic change influencing an existing high level of hazards (IPCC, 2012) and continuing urban development which creates greater vulnerability.

Both factors therefore contribute to the geohydrological risk in the Genoan area, even if the complete and irrational urbanization of valley floors seems, however, the most striking aspect (Fig. 13). The combination of the climatic analysis and the evaluation of urban sprawl through historical maps could be useful to properly assess the actual influence of climatic variations rather than land use (IPCC, 2013) on the recent increase in the geohydrological risk in the European and Mediterranean area.

The resulting increase in damage costs and the number of deaths (about 60 from 1970 in Genoa alone) can hardly be considered an acceptable level of risk (Nielsen et al., 1994). As documented by this paper, Genoa and surrounding communities have experienced significant geohydrological events over a long period of time. The meteorological, climatic and geographical conditions responsible for these events will continue for the foreseeable future and may even become more severe. This means we can define the hazard potential but can do little to change this risk component. Vulnerability as represented by the urban development potentially at risk from a future event is the only means for avoiding a continuing upward spiral of disastrous impacts. This is similar to the present situation in New Orleans, Louisiana (USA), after Hurricane Katrina, where governmental actions had resulted in promoting development in potentially hazardous areas and paying too little attention to planning in order to limit local vulnerabilities (Burbey, 2006).

Reducing risk posed by future geohydrological events requires not only knowledge about the hazards, but also taking actions to use that knowledge (De Graff et al., 2015). Future development needs to incorporate actions that maintain the natural river channel, limit further coastline progradation, avoid the constriction of the width of the river channel and counter the effect of more impervious urban surfaces. The intent would be to reduce vulnerability by increasing the community resilience to future hazardous events, resilience being "the ability to prepare and plan for, absorb, recover from, and more successfully adapt to adverse effects" (Committee on Increasing National Resilience to Hazards and Disasters, 2012). In this framework, future development could both limit adding to existing vulnerability 
and, potentially, reduce it, as developmental opportunities cause the replacement and modification of urban features, contributing to existing vulnerability. This is obviously a long-term effort involving both governmental and private institutions who will depend on the knowledge gained from the study of past geohydrological events to properly design, arrange and alter urban development in Genoa. Increasing resilience will result in a decrease in vulnerability, and in turn, reduce the risk of future geohydrological events.

Edited by: D. Gomis

Reviewed by: M. Zappa and two anonymous referees

\section{References}

Almagià, R.: Studi geografici sopra le frane in Italia, vol. 3, Società Geografica Italiana, Roma, 342 pp., 1907.

Anagnostopoulou, Chr., Tolika, K., Flocas, H., and Maheras, P.: Cyclones in the Mediterranean region: present and future climate scenarios derived from a general circulation model (HadAM3P), Adv. Geosci., 7, 9-14, doi:10.5194/adgeo-7-9-2006, 2006.

Aronica, G. T., Brigandí, G., and Morey, N.: Flash floods and debris flow in the city area of Messina, north-east part of Sicily, Italy in October 2009: the case of the Giampilieri catchment, Nat. Hazards Earth Syst. Sci., 12, 1295-1309, doi:10.5194/nhess-121295-2012, 2012.

ARPAL - Agenzia Regionale per la Protezione dell'Ambiente Liguria: Atlante climatico della Liguria, edited by: Agrillo, G. and Bonati, V., Centro Funzionale Meteo-idrologico di Protezione Civile, available at: http://www.arpal.gov.it/homepage/meteo/ analisiclimatologiche/atlante-climatico-della-liguria.html (last access: 30 November 2015), 2013.

AVI PROJECT - Flood Archive: http://wwwdb.gndci.cnr.it/ php2/avi/piene_loc.php?numero_piena $=8300027 \&$ comune $=$ Crotone\&lingua=en (last access: 30 November 2015), 1996.

Baioni, D.: Human activity and damaging landslides and floods on Madeira Island, Nat. Hazards Earth Syst. Sci., 11, 3035-3046, doi:10.5194/nhess-11-3035-2011, 2011.

Bartholy, J., Pongracz, R., and Margitppatantyus, A.: European cyclone track analysis based on Ecmwf era 40 data sets, Int. J. Climatol., 26, 1517-1527, 2006.

Begert, M., Schlegel, T., and Kirchhofer, W.: Homogeneous temperature and precipitation series of Switzerland from 1864 to 2000, Int. J. Climatol., 25, 65-80, 2005.

Blöschl, G., Nester, T., Komma, J., Parajka, J., and Perdigão, R. A. P.: The June 2013 flood in the Upper Danube Basin, and comparisons with the 2002, 1954 and 1899 floods, Hydrol. Earth Syst. Sci., 17, 5197-5212, doi:10.5194/hess-17-5197-2013, 2013.

Bossolasco, M., Cicconi, G., Dagnino, I., and Flocchini, G.: Le cause meteorologiche dell'alluvione su Genova del 7-8 ottobre 1970, Geofisica e Meteorologia, 20, 122-132, 1971.

Brandolini, P. and Ramella, A.: Eventi alluvionali e dissesti idrogeologici: il caso della Val Varenna (Liguria), in: Studi Geografici in onore di Domenico Ruocco, edited by: Citarella, F., Loffredo Editore Napoli, Napoli, 57-72, 1994.

Brandolini, P., Cevasco, A., Firpo, M., Robbiano, A., and Sacchini, A.: Geo-hydrological risk management for civil protection purposes in the urban area of Genoa (Liguria, NW Italy), Nat. Haz- ards Earth Syst. Sci., 12, 943-959, doi:10.5194/nhess-12-9432012, 2012.

Budetta, P. and De Riso, R.: The mobility of some debris flows in pyroclastic deposits of the northwestern Campanian region (southern Italy), Bull. Eng. Geol. Environ., 63, 293-302, 2004.

Burbey, R. J.: Hurricane Katrina and the paradoxes of government disaster policy: bringing about wise governmental decisions for hazardous areas, Ann. Am. Acad. Polit. Social Sci., 604, 171192, 2006.

Buzzi, A., Davolio, S., Malguzzi, P., Drofa, O., and Mastrangelo, D.: Heavy rainfall episodes over Liguria in autumn 2011: numerical forecasting experiments, Nat. Hazards Earth Syst. Sci., 14, 1325-1340, doi:10.5194/nhess-14-1325-2014, 2014.

Caredio, F., D’Amato Avanzi, G., Puccinelli, A., Trivellini, M., Venutelli, M., and Verani, M.: La catastrofe idrogeologica del 19/6/1996 in Versilia e Garfagnana (Toscana, Italia): aspetti geomorfologici e valutazioni idrauliche (Italian), Atti Convegno Internazionale ALBA 96 (Luino Ed.): "La prevenzione delle catastrofi idrogeologiche: il contributo della ricerca scientifica", 57 November 1996, CNR-IRPI, Alba 1998.

Cati, L.: L'evento alluvionale del 7-8 ottobre 1970 sui bacini dei torrenti Leiro, Polcevera e Bisagno, In: Annali Idrologici, parte 2, Istituto Poligrafico dello Stato, Roma, p. 74, 1971.

Cevasco, A., Sacchini, A., Robbiano, A., and Vincenzi, E.: Evaluation of rainfall thresholds for triggering shallow landslides on the Genoa Municipality area (Italy): the case study of the Bisagno Valley, Ital. J. Eng. Geol. Environ., 1, 35-50, 2010.

Cevasco, A., Brandolini, P., and Scopesi, C.: Relationships between geo-hydrological processes induced by heavy rainfall and landuse: the case of 25 October 2011 in the Vernazza catchment (Cinque Terre, NW Italy), J. Maps, 9, 289-298, 2013.

Cipolla, F., Conti, M., Russo, D., and Sebastiani, C.: Mappatura delle aree esondate, sintesi dei danni e sintesi dei dati storici, in: Rapporto di evento Savona 22/9, Genova 27/9/1992, CNR, GNDFI, Roma, 1993.

Cipolla, F., Guzzetti, F., Lolli, O., Pagliacci, S., Sebastiani, C., and Siccardi, F.: Catalogo nazionale delle località colpite da frane e da inondazioni: verso un utilizzo più maturo dell'informazione, Accademia Nazionale dei Lincei, 154, Il rischio idrogeologico e la difesa del suolo, Accademia Nazionale dei Lincei, Rome, 1999.

CityRailways: Urbanismi in Italia 2011, available at: www. cityrailways.net (last access: 30 November 2015), 2011.

Coles, S.: An introduction to statistical modeling of extreme values, Springer Verlag, London, 209 pp., 2001.

Committee on Increasing National Resilience to Hazards and Disasters, Committee on Science, Engineering, and Public Policy, and The National Academies: Disaster Resilience: A National Imperative, National Academies Press, Washington D.C., p. 244, 2012.

Conti, M., La Barbera, P., and Lanza, L. G.: Analisi idrologica d'evento: modellazione su base GIS e stima delle portate di piena, in: Rapporto di evento, Savona 22 settembre 1992-Genova 27 settembre 1992, a cura delle unità operative del CNR-GNDCI, Dip. Protezione Civile, Roma, 1994.

Corominas, J. and Alonso, E. E.: Geomorphological effects of extreme floods (November 1982) in the southern Pyrenees, Proc. of II Lausanne Symposia, August 1990, in: Hydrology in mountainous region II. Artificial reservoirs, water and slopes, edited by: 
Sinniger, R. O. and Monbaron, M., 295-302, IAHS publ. no. 194, Wallingford, UK, 1990 295-302, 1990.

Corriere della Sera newspaper: Historical archive: newspaper of 14 march 1995, http://archiviostorico.corriere.it/1995/marzo/14/ maltempo_uccideSiciliaginocchio_co_89503141281.shtml (last access: 30 November 2015), 1995.

Corriere della Sera newspaper: Historical archive: newspaper of 7 November 2000, http://archiviostorico. corriere.it/2000/novembre/07/Alluvione_Liguriatremorti_ miliardico00011077784.shtml, (last access: 30 November 2015), 2000a.

Corriere della Sera newspaper: Historical archive: newspaper of 24 November 2000, http://archiviostorico. corriere.it/2000/novembre/24/Liguria_tornaalluvionedue_ vittimeco00011245556.shtml, (last access: 30 November 2015), 2000b.

Corriere della Sera newspaper: http://www.corriere.it/cronache/13 novembre_18, (last access: 30 November 2015), 2013.

Cortemiglia, G. C.: Approccio di analisi climatica alle serie termopluviometriche storiche italiane, in: La variabilità del clima locale relazionata ai fenomeni di cambiamento climatico globale, edited by: Cortemiglia, G. C., Patron Editore, Bologna, 99-127, 2006.

Dagnino, I., Flocchini, G., and Palau, C.: Le precipitazioni del 610 ottobre 1977 sulla Liguria Centrale, Atti XV I.T.A.M., 267270, 1978.

De Graff, J. V., Anderson, M. G., and Holcombe, E.: Landslide Risk Reduction-Complementary Routes to Learning, in: Proc. IAEG2014 "Engineering Geology for Society and Territory", vol. 5, edited by: Lollino G., Manconi A., Guzzetti F., Culshaw M., Bobrowsky P., and Luino F., Springer International Publishing, Springer International Publishing Switzerland, 727730, 2015 .

Disse, M. and Engel, H.: Flood events in the Rhine basin: Genesis, influences and mitigation, Nat. Hazards, 23, 271-290, 2001.

Faccini, F., Brandolini, P., Robbiano, A., Perasso, L., and Sola, A.: Instability, precipitation phenomena and land planning: the flood of 2002 in lower Lavagna valley (Eastern Liguria, Italy), Geografia Fisica e Dinamica Quaternaria, Suppl. VII, Geografia Fisica e Dinamica Quaternaria, 145-153, 2005.

Faccini, F., Piccazzo, M., and Robbiano, A.: Natural hazards in San Fruttuoso of Camogli (Portofino Park, Italy): a case study of a debris flow in a coastal environment, Bollettino della Società Geologica Italiana (It. Jour. Geol.), 128, 641-654, 2009.

Faccini, F., Robbiano, A., and Sacchini, A.: Geomorphic hazards and intense rainfall: the case study of the Recco Stream catchment (Eastern Liguria, Italy), Nat. Hazards Earth Syst. Sci., 12, 893-903, doi:10.5194/nhess-12-893-2012, 2012.

Faccini, F., Luino, F., Sacchini, A., and Turconi, L.: Flash flood events and urban development in Genoa (Italy): lost in translation, in: Proc. IAEG2014 "Engineering Geology for Society and Territory”, vol. 5, part II, edited by: Lollino, G., Manconi, A., Guzzetti, F., Culshaw, M., Bobrowsky, P., and Luino F., Springer International Publishing Switzerland, 797-801, 2014.

Faccini, F., Luino, F., Paliaga, G., Sacchini, A., and Turconi L.: Yet another disaster flood of the Bisagno stream in Genoa (Liguria, Italy) - October the $9^{\text {th }}-10^{\text {th }} 2014$ event, Rendiconti Online Soc. Geol. It., 35, 128-131, 2015a.
Faccini, F., Luino, F., Sacchini, A., and Turconi, L.: The $4^{\text {th }}$ October 2010 flash flood event in Genoa Sestri Ponente (Liguria, Italy), Disaster Adv., 8, 1-14, 2015 b.

Faccini, F., Giostrella, P., Lazzeri, R., Melillo, M., Raso, E., and Roccati, A.: The $10^{\text {th }}$ November 2014 flash-flood event in Chiavari city (Eastern Liguria, Italy), Rendiconti Online Soc. Geol. It., 35, 124-127, 2015c.

Glade, T., Albini, P., and Frances, F. (Eds.): The use of historical data in natural hazard assessments, Advances of Technological and Natural Hazard Research, Kluwer, 220 pp., 2001.

Govi, M. and Turitto, O.: Recent and past floods in Northern Italy. River Flood Disasters, ICSU-SC-IDNDR Workshop, 1996, Koblenz, Germany, 13-32, 1997.

Grams, C. M., Binder, H., Pfahl, S., Piaget, N., and Wernli, H.: Atmospheric processes triggering the central European floods in June 2013, Nat. Hazards Earth Syst. Sci., 14, 1691-1702, doi:10.5194/nhess-14-1691-2014, 2014.

Guzzetti, F., Cardinali, M., Reichenbach, P., Cipolla, F., Sebastiani, C., Galli, M., and Salvati, P.: Landslides triggered by the 23 November 2000 rainfall event in the Imperia Province, Western Liguria, Italy, Eng. Geol., 73, 229-245, 2004.

Hall, J., Arheimer, B., Borga, M., Brázdil, R., Claps, P., Kiss, A., Kjeldsen, T. R., Kriaučiūnienè, J., Kundzewicz, Z. W., Lang, M., Llasat, M. C., Macdonald, N., McIntyre, N., Mediero, L., Merz, B., Merz, R., Molnar, P., Montanari, A., Neuhold, C., Parajka, J., Perdigão, R. A. P., Plavcová, L., Rogger, M., Salinas, J. L., Sauquet, E., Schär, C., Szolgay, J., Viglione, A., and Blöschl, G.: Understanding flood regime changes in Europe: a state-of-the-art assessment, Hydrol. Earth Syst. Sci., 18, 27352772, doi:10.5194/hess-18-2735-2014, 2014.

Hargrove, W. W., Hoffman, F. M., and Hessburg, P. F.: Mapcurves, a quantitative method for comparing categorical maps, J. Geogr. Syst., 8, 187-208, 2006.

Hilker, N., Badoux, A., and Hegg, C.: The Swiss flood and landslide damage database 1972-2007, Nat. Hazards Earth Syst. Sci., 9, 913-925, doi:10.5194/nhess-9-913-2009, 2009.

Hipel, K. W. and McLeod, A. I.: Time Series Modelling of Water Resources and Environmental Systems, available at: http://www. stats.uwo.ca/faculty/aim/1994Book (last access: 30 November 2015), 2005.

Inglese, I., Fantoli, G., and Canepa, R.: Relazione sulla portata massima del Torrente Bisagno, sulla condottura urbana dello stesso, Bacigalupi editore, Genova, 1909.

IPCC - Intergovernmental Panel on Climate Change: Managing the risks of extreme events and disasters to advance climate change adaption (SREX), Intergovernmental Panel on Climate Change, Cambridge University Press, Cambridge, 582 pp., 2012.

IPCC - Intergovernmental Panel on Climate Change: Climate Change 2013: The Physical Science Basis, in: Contribution of Working Group I to the Fifth Assessment Report of the Intergovernmental Panel on Climate Change, edited by: Stocker, T. F., Qin, D., Plattner, G.-K., Tignor, M., Allen, S. K., Boschung, J., Nauels, A., Xia, Y., Bex, V., and Midgley, P. M., Cambridge University Press, Cambridge, UK and New York, NY, USA, 1535 pp., 2013.

ISTAT: $14^{\circ}$ Censimento Generale della Popolazione e delle Abitazioni, http://dawinci.istat.it/MD/ (last access: 30 November 2015), 2011. 
Italian Air Force: Atlante Climatico d'Italia, available at: http: //clima.meteoam.it/atlanteClimatico.php (last access: 30 November 2015), 2009.

Jansà, A.: A general view about Mediterranean meteorology: cyclones and hazardous weather, In: Proceedings of the INM/WMO International Symposium on Cyclones and HazardousWeather in the Mediterranean, Instituto Nacional de Meteorología and Universitat de les Illes Balears, Palma de Mallorca, 33-42, 1997.

Jansa, A., Alpert, P., Arbogast, P., Buzzi, A., Ivancan-Picek, B., Kotroni, V., Llasat, M. C., Ramis, C., Richard, E., Romero, R., and Speranza, A.: MEDEX: a general overview, Nat. Hazards Earth Syst. Sci., 14, 1965-1984, doi:10.5194/nhess-14-19652014, 2014.

Kellens, W., Vanneuville, W., Verfallie, E., Meire, E., Deckers, P., and De Maeyer, P.: Flood Risk Management in Flanders: Past Developments and Future Challenges, Water Resour. Manage., 27, 3585-3606, 2013.

King, K. W., Harmel, R. D., and Fausey, N. R.: Development and sensitivity of a method to select time-and flow-paced storm event sampling intervals for headwater streams, J. Soil Water Conserv., 60, 323-330, 2005.

Kiss, A., Brázdil, R., and Blöschl, G. (Eds.): Floods and their changes in historical times - a European perspective, Hydrol. Earth Syst. Sci., http://www.hydrol-earth-syst-sci.net/special_ issue 191.html, 2014.

Llasat, M. C., Barriendos, M., Barrera, A., and Rigo, T.: Floods in Catalonia (NE Spain) since the $14^{\text {th }}$ century. Climatological and meteorological aspects from historical documentary sources and old instrumental records, J, Hydrol. Palaeofloods Hist. Data, 313, 32-47, 2005.

Luino, F.: The flood and landslide event of November 4-6, 1994 in Piedmont Region (North-West Italy): causes and related effects in Tanaro Valley, XXII General Assembly dell'European Geophysical Society, 21-25 April 1997, Vienna, Austria, Elsevier Science Ltd, Phys. Chem. Earth (A), 24, 123-129, Elsevier Science Ltd., 1999.

Luino, F.: Sequence of instability processes triggered by heavy rainfall in the northern Italy, Geomorphology, 66, 13-39, 2005.

Luino, F.: A Flood Can Point Out Improper Land-Use Planning: The Case of Alessandria Town (Piedmont, Northern Italy), in: Proc. IAEG2014 "Engineering Geology for Society and Territory, vol. 5, part II, edited by: Lollino, G., Manconi, A., Guzzetti, F., Culshaw, M., Bobrowsky, P., and Luino, F., Springer International Publishing Switzerland, 787-792, 2014.

Luino, F., Belloni, A., Padovan, N. in collaboration with Bassi, M., Bossuto, P., and Fassi, P.: Historical and geomorphological analysis as a research tool for the identification of flood-prone zones and its role in the revision of town planning: the Oglio basin (Valcamonica - Northern Italy), 9th Congress of the IAEG, 1620 September 2002, Durban, South Africa, 191-200, 2002.

Luino, F., Turconi, L., Petrea, C., and Nigrelli, G.: Uncorrected land-use planning highlighted by flooding: the Alba case study (Piedmont, Italy), Nat. Hazards Earth Syst. Sci., 12, 2329-2346, doi:10.5194/nhess-12-2329-2012, 2012.

Mann, H. B.: Non parametric tests against trend, Econometrica, 13, 245-259, 1945.

Montanari, A., Young, G., Savenije, H. H. G., Hughes, D., Wagener, T., Ren, L. L., Koutsoyiannis, D., Cudennec, C., Toth, E.,
Grimaldi, S., Blöschl, G., Sivapalan, M., Beven, K., Gupta, H., Hipsey, M., Schaefli, B., Arheimer, B., Boegh, E., Schymanski, S. J., Di Baldassarre, G., Yu, B., Hubert, P., Huang, Y., Schumann, A., Post, D., Srinivasan, V., Harman, C., Thompson, S., Rogger, M., Viglione, A., McMillan, H., Characklis, G., Pang, Z., and Belyaev, V.: "Panta Rhei-Everything Flows": Change in hydrology and society - The IAHS Scientific Decade 20132022, Hydrolog. Sci. J., 58, 1256-1275, 2013.

Montani, A., Marsigli, C., Nerozzi, F., Paccagnella, T., Tibaldi, S., and Buizza, R.: The Soverato flood in Southern Italy: performance of global and limited-area ensemble forecasts, HAL Id: hal-00302207, https://hal.archives-ouvertes.fr/hal-00302207 (last access: 30 November 2015), 2003.

Nielsen, N. M., Hartford, D. N. D., and MacDonald, J. J.: Selection of tolerable risk criteria for dam safety decision making, Proc. 1994 Canadian Dam Safety Conference, Winnipeg, Manitoba, BiTech Publishers, Vancouver, 355-369, 1994.

Nimbus: official site of the Società Meteorologica Italiana (SMI), http://www.nimbus.it/eventi/2012/121114AlluvioneCentroItalia. htm (last access: 30 November 2015), 2012.

Nirupama, N. and Simonovic, S. P.: Increase of flood risk due to urbanisation: a canadian example, Nat. Hazards, 40, 25-41, 2007.

Pagani, A.: La Biblioteque Universelle de Geneve, 23 November 1822 .

Pasquale, V., Russo, G., Sacchini, A., and Verdoya, M.: Precipitation rate as a signal of recent climatic variations, Ann. Meterol. 30, 278-281, 1994.

Petrucci, O., Pasqua, A. A., and Polemio, M.: Flash Flood Occurrences Since the $17^{\text {th }}$ Century in Steep Drainage Basins in Southern Italy, Environ. Manage., 50, 807-818, 2012.

Porfido, S., Esposito, E., Alaia, F., Molisso, F., and Sacchi, M.: The use of documentary sources for reconstructing flood chronologies on the Amalfi rocky coast (Southern Italy), in: Geohazard in Rocky Coastal Areas, Special Pub. Geological Society of London no. 322, Geological Society of London, London, 173-187, 2009.

Regione Marche: Dip. per le Politiche Integrate di Sicurezza e per la Prot. Civile Centro Funz. per la Meteorologia, l'Idrologia e la Sismologia, RAPPORTO DI EVENTO 1-3 marzo 2011, available at: http://www.protezionecivile.marche.it/bo/allegati/files/ RapportiEvento/Rapporto_Evento1-3MARZOagg20110314_ +allegati.pdf (last access: 30 November 2015), 2011.

Repubblica newspaper: http://www.repubblica.it/cronaca/2013/ 11/19/news/sardegna_inginocchioil_maltempofrastrage_

16mortidispersi_4travoltidalponte-71336719/ (last access: 30 November 2015), 2013.

Russo, G. and Sacchini, A.: Brief survey on recurrences of extreme rainfalls in Genoa, Italy, Idojaras, 98, 251-260, 1994.

Russo, G., Eva, C., Palau, C., Caneva, A., and Sacchini, A.: The recent increase in the precipitation rate, as seen in an ultracentennial series of precipitation, Il Nuovo Cimento, 23, 39-51, 2000.

Sacchini, A., Ferraris, F., Faccini, F., and Firpo, M.: Environmental climatic maps of Liguria, J. Maps, 8, 199-207, 2012.

Saéz de Cámara, E., Gangoiti, G., Alonso, L., Navazo, M., Gòmez, N., Iza, J., Garcìa, J. A., Ilardia, J. L., and Millàn, M. M.: Water vapour accumulation mechanisms in the Western Mediterranean Basin and the development of European extreme rainfalls, Tethys, J. Weather Clim. W. Mediterran., 8, 101-117, 2011. 
Silvestro, F., Gabellani, S., Giannoni, F., Parodi, A., Rebora, N., Rudari, R., and Siccardi, F.: A hydrological analysis of the 4 November 2011 event in Genoa, Nat. Hazards Earth Syst. Sci., 12, 2743-2752, doi:10.5194/nhess-12-2743-2012, 2012.

Trigo, I. F., Davies, T. D., and Bigg, G. R.: Objective climatology of cyclones in the Mediterranean region, J. Climate, 12, 1685-1696, 1999.

Tropeano, D. and Turconi, L.: Using Historical Documents for Landslide, Debris Flow and Stream Flood Prevention, Applications in Northern Italy, Nat. Hazards, 31, 663-679, 2004.

Tropeano, D., Chiarle, M., Deganutti, A., Mortara, G., Moscariello, A., Mercalli, L., in collaboration with Dutto, F., Godone, F., Massobrio, R., and Beretta, E.: Gli eventi alluvionali del 22 e 27 settembre 1992 in Liguria. Studio idrologico e geomorfologico, Supplemento a GEAM, Quaderni di studi e di documentazione no. 13, Anno XXX, no. 4, Associazione Mineraria Subalpina, Torino, 3-37, 1993.
Tropeano, D., Arattano, M., Deganutti, A. M., Luino, F., Ciamartori, L., and Dutto, F.: L'evento alluvionale del 22-25 settembre 1993 in Liguria, Piemonte e Val d'Aosta, Aspetti idrologici e geomorfologici, Suppl. GEAM, no. 2-3, Torino, 42 pp., 1995.

Tropeano, D., Luino, F., and Turconi, L.: Evento alluvionale del 14-15 ottobre nell'Italia Nord-Occidentale, Fenomeni ed effetti, XXXVII, no. 4, GEAM, Torino, 203-216, 2000. 